إثنكاليه التوفيق بين التحول الايمقر اطي والموروث التقليلي للنظام

السياسي المغربي

محمد صالح شطيب

مدرس مساعد/ كلبة العلوم السياسية/ جامعة الموصل

مستخلص البحث

ان واقع النظام السياسي المغربي المعاصر يتحدد اعتمادا على تلاته اعتبــارات

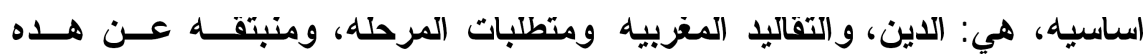

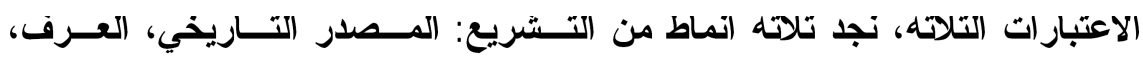

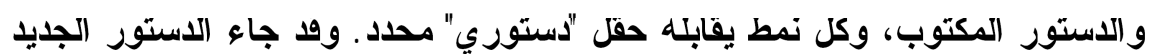

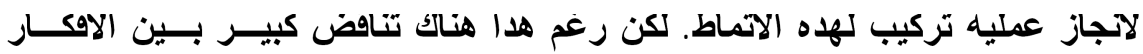
الإسلاميه والتاريخيه المتمتله بإمارة المؤمنين في الفصل 19 من الدستور المغربي،

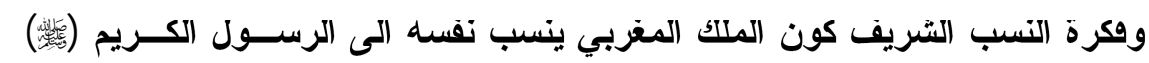
وهلا ما يسم (بالتقليديه)، وبين محاوله الملك ربط هدا التقليا بالحداته من خــلدل الاستور والاككار المقتبسه من الاساتير الغربيه وبالاخص الدستور الفرنسي وهلا ما جعل الر ابط السياسي و الفكري والعقائدي مختلا وغير متزن دستوريا.

المقدمها

ستظل قضية الديمقر اطية وتطور ها على مستوى النظم السياسية فـي

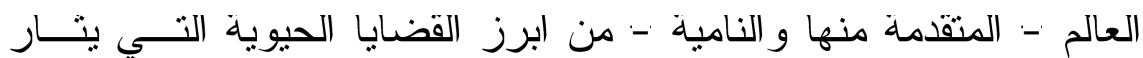
حولها النقاش في مطلع الالفية الجديدة. فالتحول نحو الديمقر اطبة في الحكم بات بشكل إحدى الموجات الكبرى المى التي شهذها العالم المعاصر و التي بدات تتبلور منذ منتصف الــسبعينات و الثمانبات حتى ناكدت ملامحها في التسعينات. 
لقد بدات مؤشرات التحول الديمقر اطي في المملكة المغربية في مطلع التشعينات من القرن العشرين ودلك من خلال مجمو عة من التحو لات التي

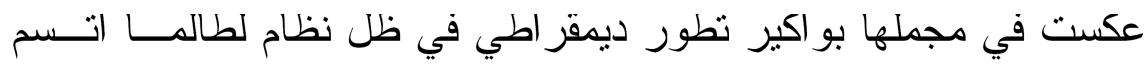
بالسلطة المفرطة ودلك في محاولة لخلق تو ازن بين كل مــن الـــو اجعتين التقليدية و الحديثة إذ تمنل الشرعية الدينية اهم ركائز النظام المغربي التي لئي

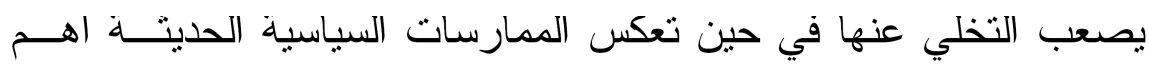
موجبات التحول الديمقر اطي.

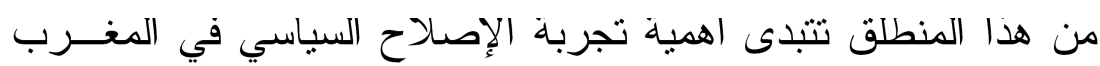

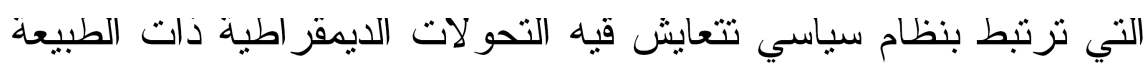

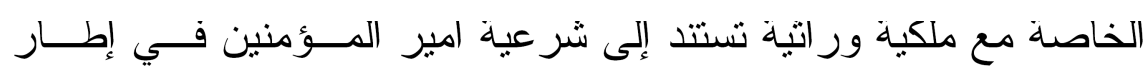

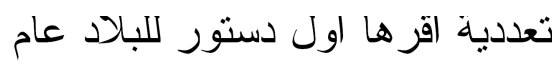

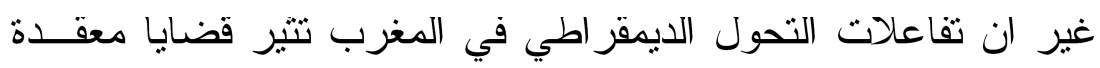

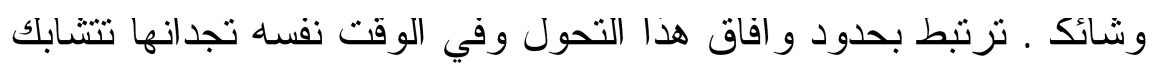
مع موضوع اخر وهو محاو لات تقسير استمر ارية النظام السياسي الملكي

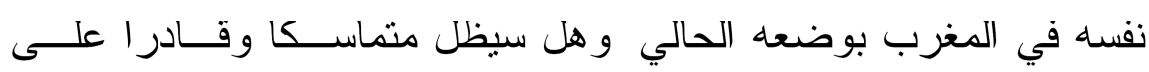
النكيف مع المتغير ات الحادة و العاصفة في النظام الدولي و على المستويين

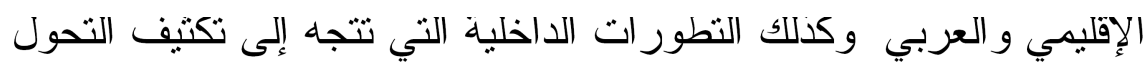
الاقتصادي الذي تدفع إليه هيئات النمويل الدولية.

\section{إشكاليه البحث}

يحاول النظام السياسي المغربي الإبقاء على هيمنة المؤسسة الملكيــة، اي ان الملك يملك ويحكم، وفي الوقت نفسه بسعى للتجاوب مع مقتضيات التغير الديمقر اطي الني تستوجب الحد من سلطة الملك. 


\section{فرضيه البحث}

ان النظام السياسي في المغرب يجمع بين مصادر منباينـــة للــشر عية السياسية تتر اوح ما بين المصادر التقليدية القائمة على الــدين و العــرق.

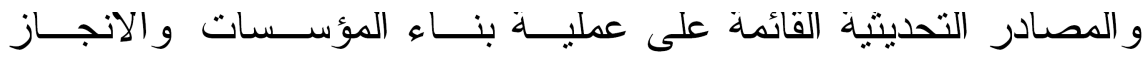
السياسي. و هذه المصادر غالبا ما تتتاقض. ذلك إن الاعتماد المفرط مــن قل النظام على النوع الاول يسفر عن اتار سلبية في مدى مؤسسية النظام و ادائه السياسي.

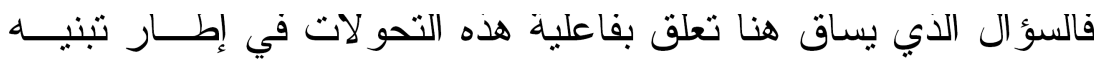

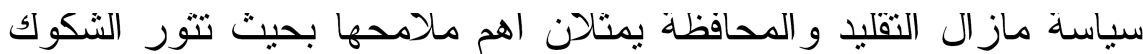
حول مدى إمكانية استيعابها لانماط ديمقر اطبة للممارسة السياسية. وفي هذا السياق تعكف الدر اسة على استجلاء طبيعة هذه العلاقة التي

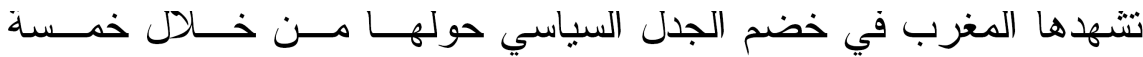
محاور : - مأن

$$
\text { تاتيا: بيئه التحول خصائص النظام السياسي المغربي. }
$$
تالتا: رؤيه المؤسسه الملكيه و المعارضه للإصلاح السياسي. رابعا: ملامح الإصلاح الدستوري هي النظام السياسي المغربي. خامسا: ملامـ التحول الايمقر اطي في المغرب.

$$
\text { اولا - خصائص النظام السياسي المغزبي }
$$

لعل اهم خاصبية تمبز الكثير من الانظمة السياسية لبلدان العالم التالث هو ان "رئاسة الدولة" تبقى المؤسسة المحورية التي يقوم عليها كل هرم السلطة و التي من خلالها تستمد كل السلطات وتتحرك كل الاجهزة، ومن لنو 
تم فإن رئيس الدولة يعد الشخصية السياسية الاولى التي تشخص جميـع

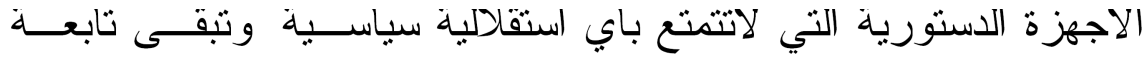

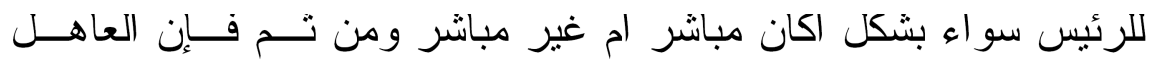
المغربي هو ابرز و اهم عنصر في الحياة السياسية المغربية، وهو المبر المحور

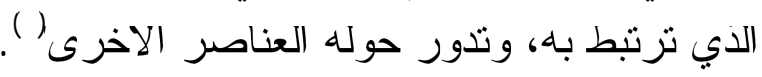
فنظام الحكم في المغرب هو نظام ملكية دستورية ديمقر اطية اجتماعية

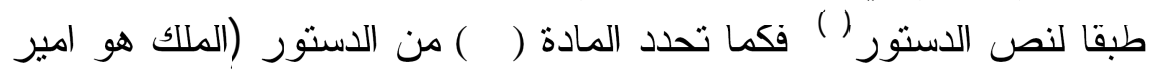

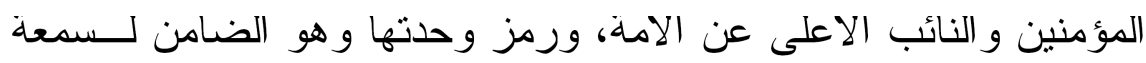

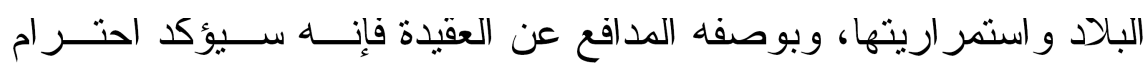

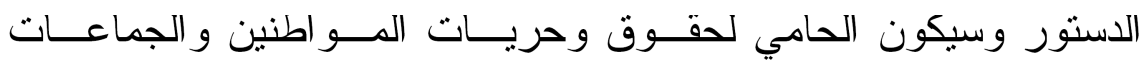
و التظظيمات الاجتماعية)(")، يتضح من هذه المادة ان الملك امير المؤمنين

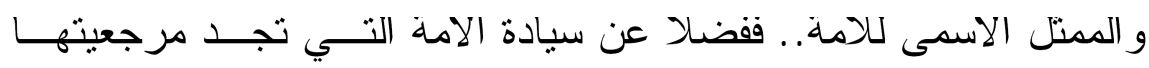

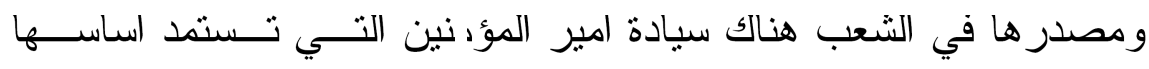

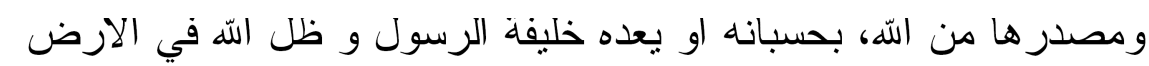

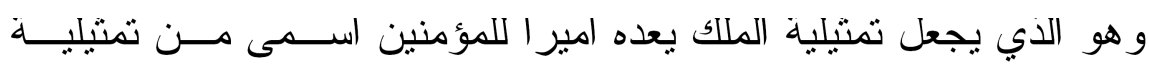

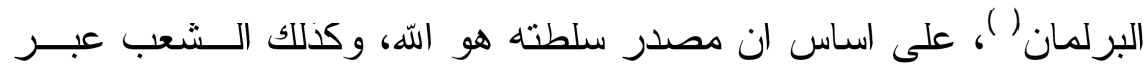

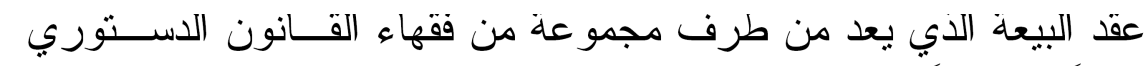

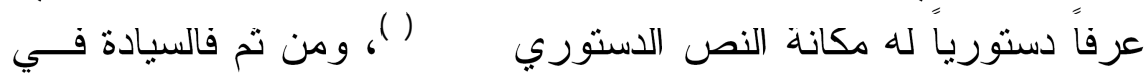

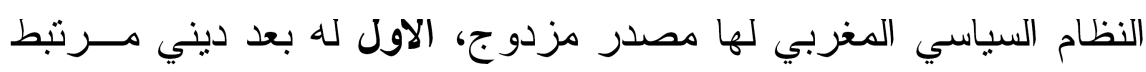

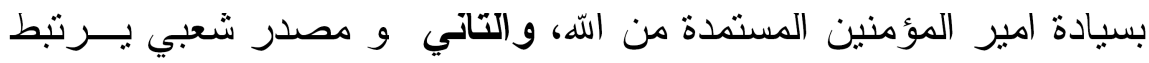

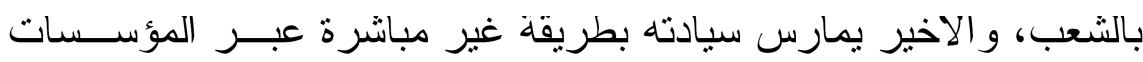

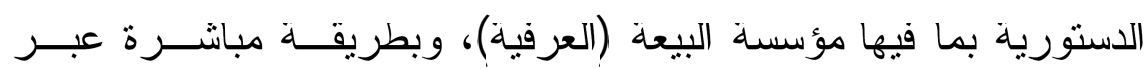
الاستقنتاء (7). 
إدا من خلال ما تقدم ايضـا يتضـح ان هناك مجمو علة مــن المرنكــزات الاساسية الني بستند عليها النظام الملكي المغربي و اهمها (V): = فكرة البيعة من زعماء القبائل وكبــار المـسئولين و العلمـــاء كــامير للمؤمنين.

= إن الملك يمارس دوره "كحكم" بين الفر قاء و القبائل وفئات الشعب. = إن الملك يمارس دوره كضامن لوحدة البلاد و استقر ارها السياسي.

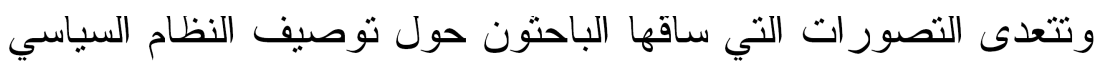
المغربي وتتحصر في وصفه بانه نظام يجمع بين الثقليدية و الحداثة، و انه

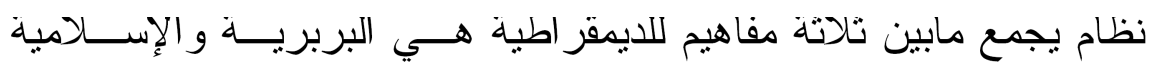
و الغربية التي تتعايش لنكسب الديمقر اطية المغربية طابعا مختلطا و احيانا متنلقال(). ولكنه في الغالب غير مسثقر سياسيا،او انه نظام رعوي ينسم

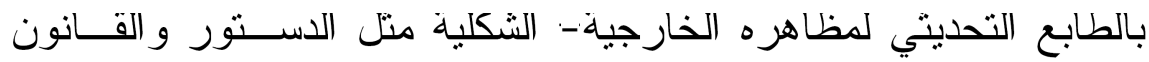
المكتوب ووجود جهاز إدارة للدولة، ولكن يستمر الطابع الرعوي مهيمنا على ادائه و الياته، كما يوصف بانه نظام يجمع بين نمطين من الشّرعية،

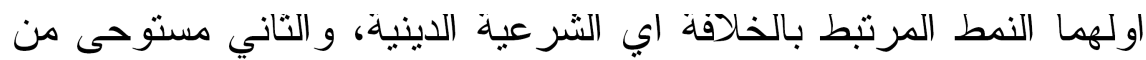
الديمقر اطية التحررية، و هناك من برى إن هذا النتاقض مرجعه الطبيعــة

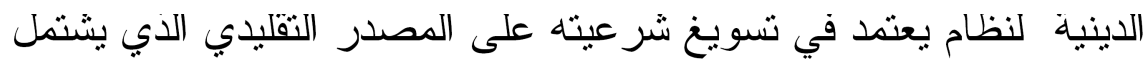

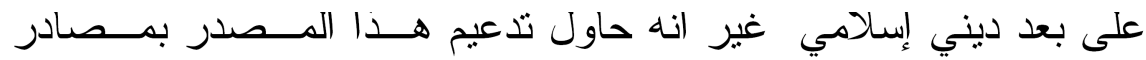
إضافية من خلال إسباغ مظاهر العقلانية القانونية كمصدر اخر لـانية للشرعية

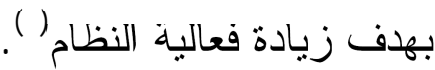
وفي كل الاحوال يمكن إيجاز اهم ملامح النظام السياسي المغربي فيما يأتي: - هيمنة الملك على الحياة السياسية، إذ ان القصر هو محــرك الحيــاة

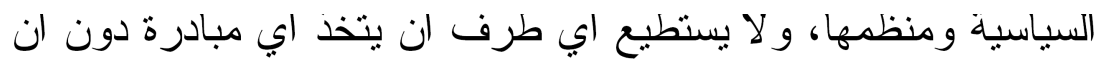




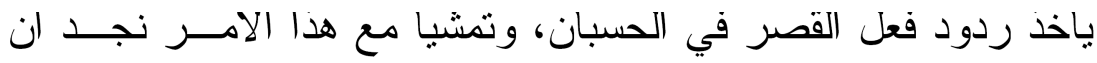

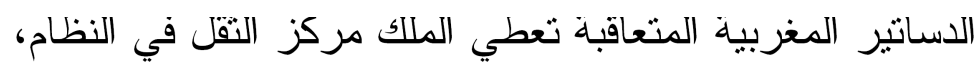
فالملك بالمغرب يعين الوزير الاول، و الحكومة المغربية مـسئولة

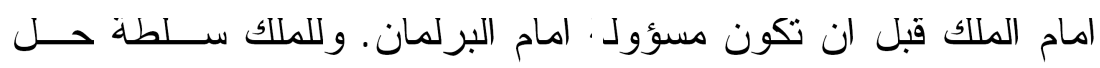
البرلمان وهذا من شانه فتح المجال لممارسة السلطة النشريعية، علاوة على إعلان حالة الطوارئ وهي سلطة غير محدودة، كما يمكن للملك

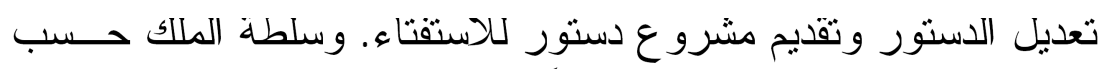

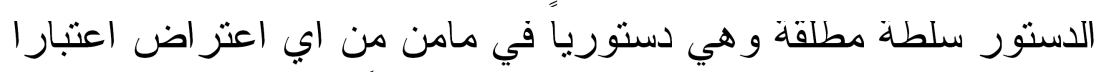
لان شخص الملك مقدس لا تتنهك حرمنه. علماً ان الحصانة البرلمانية

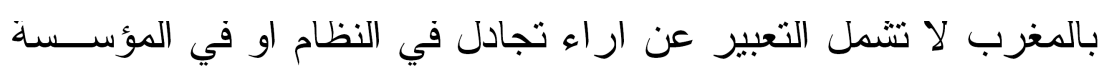
الملكية (- (1)

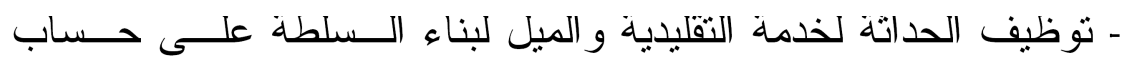

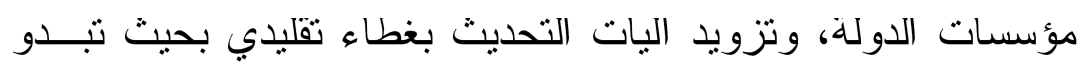

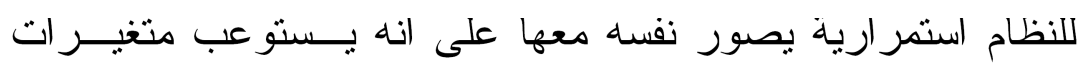
الحداثة دون تناقض.

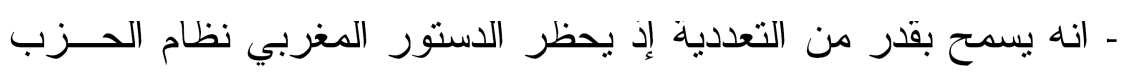

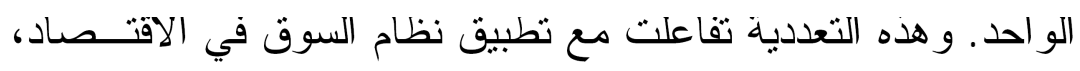

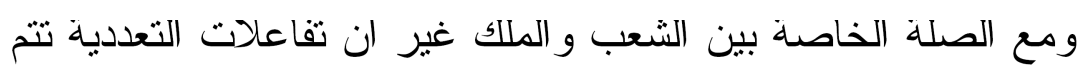
وفق عدد من القو اعد غير الرسمية.

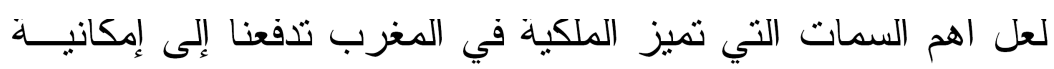

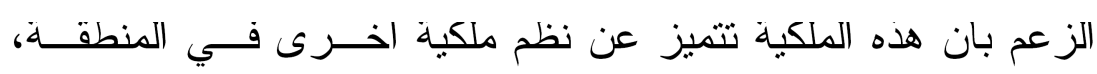
وبخاصة تلك النظم الور انية في بلاد الخليج العربي، فالملكية المغربية

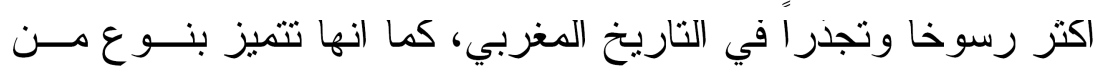

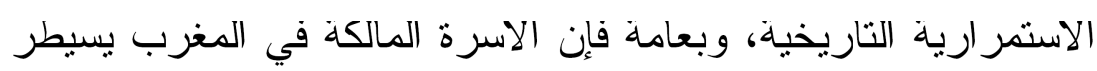

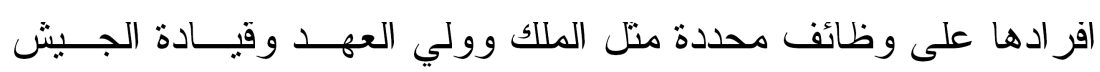




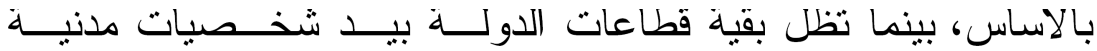

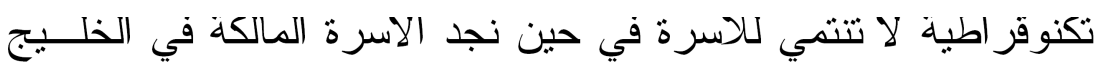

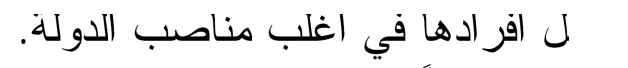

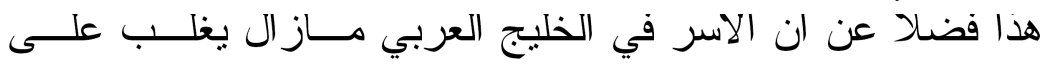

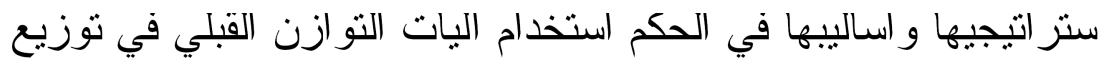

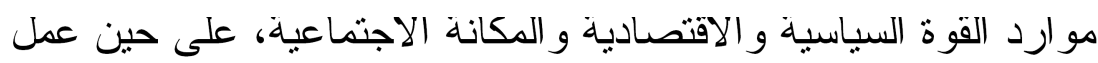

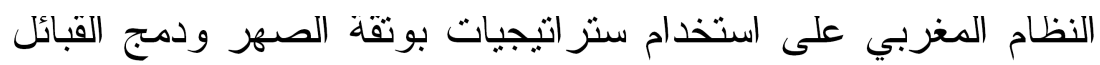

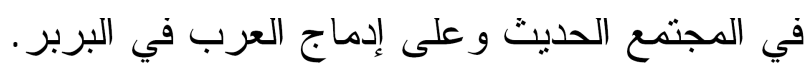

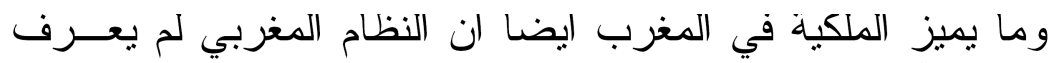

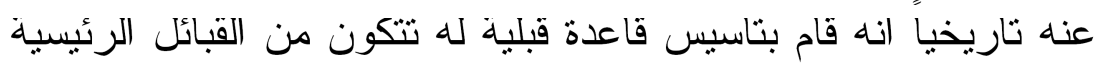

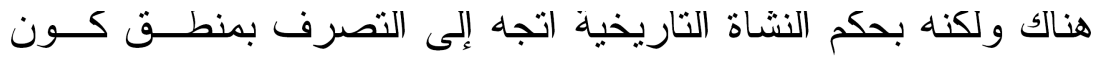

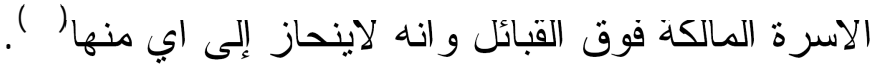

\section{تاتيا - بيئه التحول الديمقراطي في المغرب}

تمة عناصر عدة تتضمنها البيئة المحيطة بالنظام السياسي و الني تؤَتر في حركته، ومن ثم قابليته للنحول الديمقر اطي و اهمها: - الظروف الاوتصاديه والاجتماعيه: عمدت الدولة عام إلى عملية

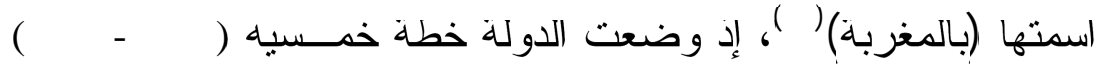

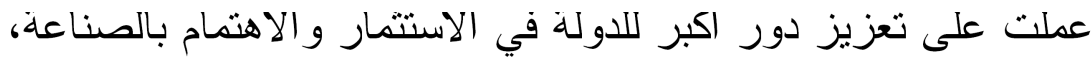

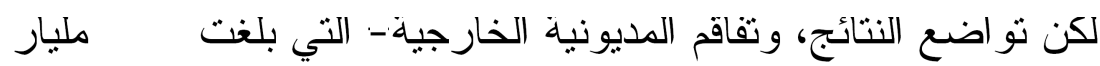

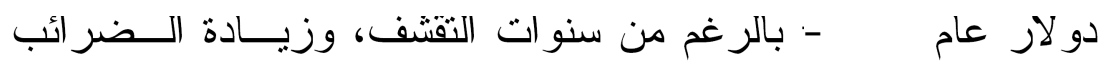

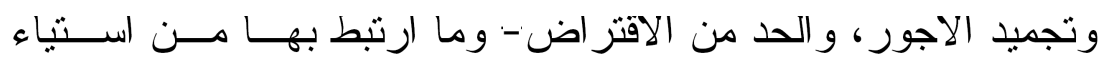

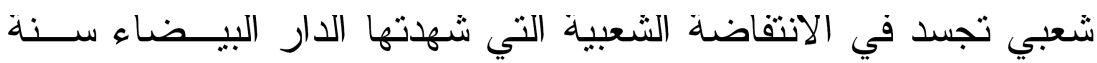

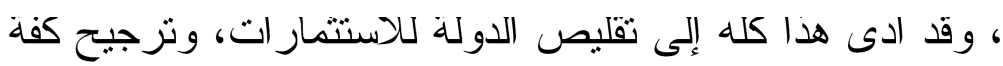




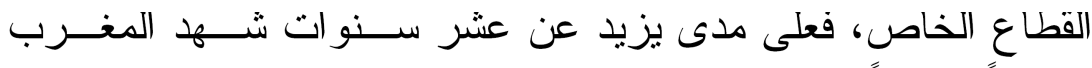

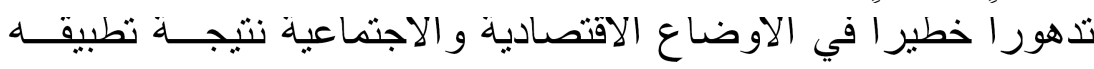

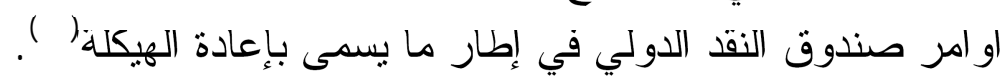

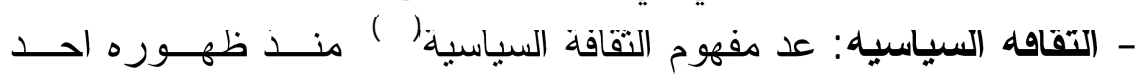

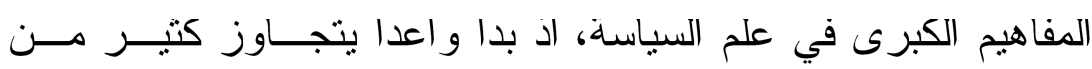

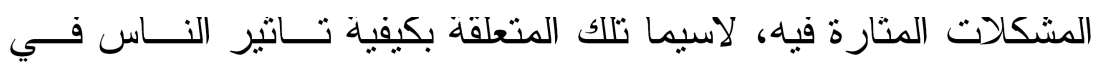
النظام السياسي وطبيعة تفاعلهم على المستوى الكلي و الجزئي.

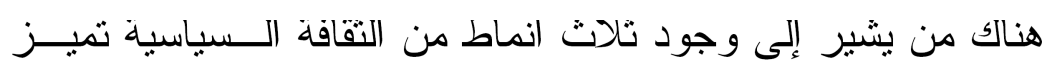

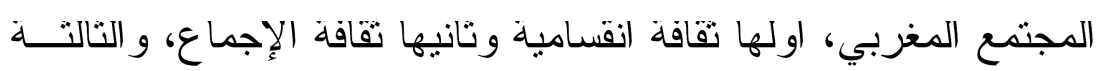
التي لاتز ال تعاني من التضبيق هي ثقافة المشاركة،

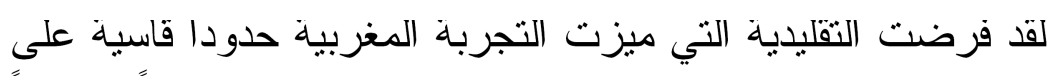

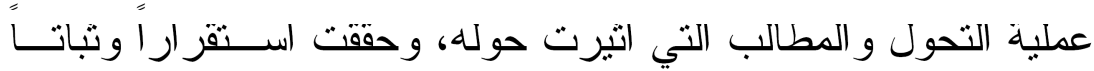
نسبياً يندر ان نجد له نظير ا، بالر غم من بعض التغير ات و المستحدثات

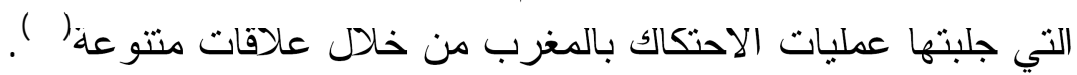

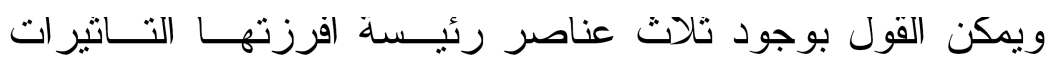
التقليدية الني تسم التقافة السياسية المغربية: - تحييد الإسـام السياسي بفعل ان الملك هو امبر المؤمنين وان النظـــــام

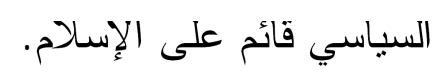

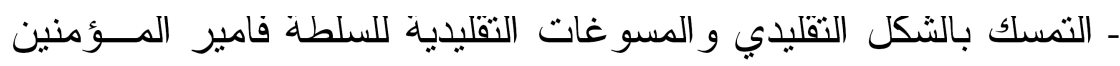

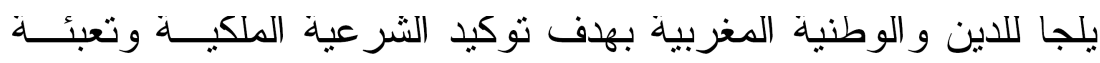

$$
\text { التابيد للعرش الملكي. }
$$
- تعبير الحركة السياسية عن و اقع مختلط من التقلبدية و الحداثة.

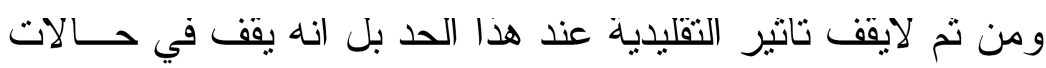

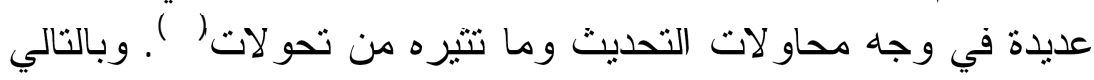


فإن نمط الثقافة السياسية القائم في المغرب لا يساعد على حفز معدلات التحول الديمقر اطي بل ويمكننا القول انه يمنل معوقا في سبيلها.

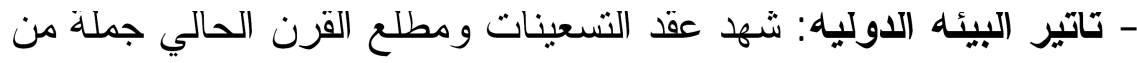
النطور ات الدولية الهامة ذات التاثيرات القائمة و المحتملة على النطور

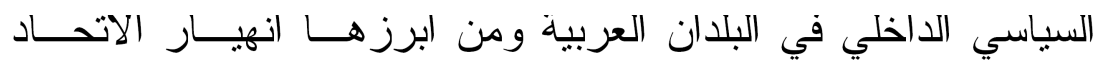
السوفيتي و الكنتلة الاشتر اكية و التحول نحو نظام احادي القطبية وتتامي

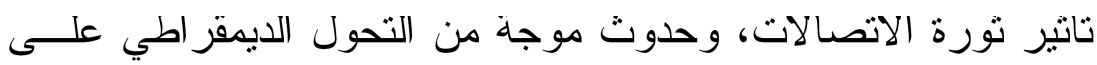
الصعيد العالمي خلال الربع الاخير من القرن العشرين ونتــامي دور

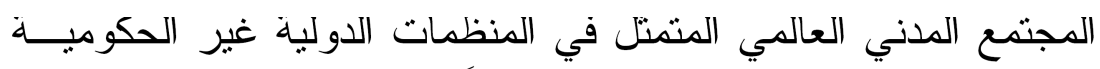

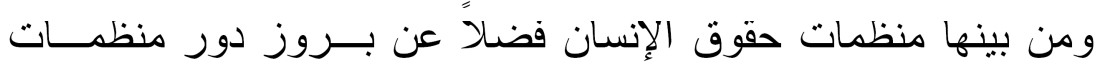
التمويل الدولية وفي مقدمتها صندوق النقد و البنك الدوليين في توجيه

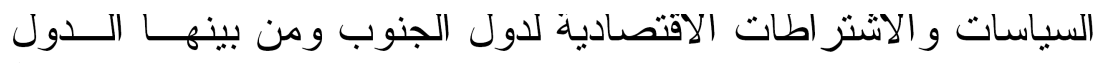
العربية وخاصة تلك الدول التي تلجا إلى المؤسسات المعنيـــة ســـياً للحصول على قروض وتسهيلات اقتصادية منل المغرب(IV). وبطبيعة

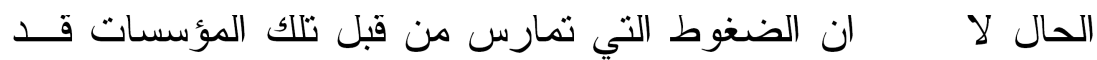

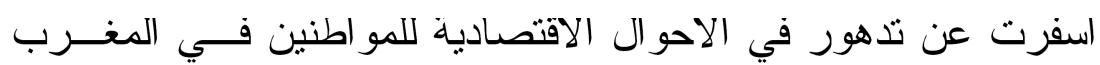

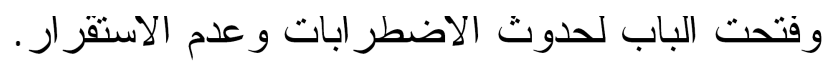

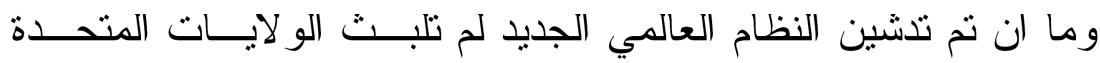

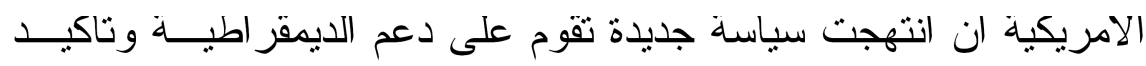

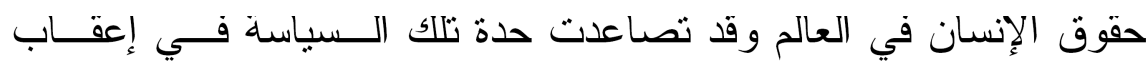
هجمات ايلول فبدا "الهجوم الديمقر اطي"' على المنطقة العربية

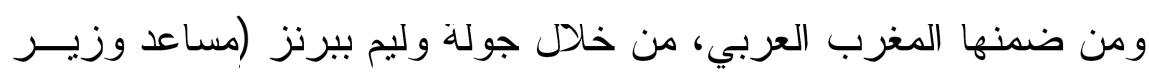

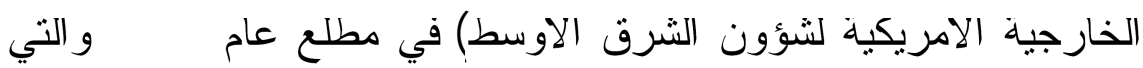

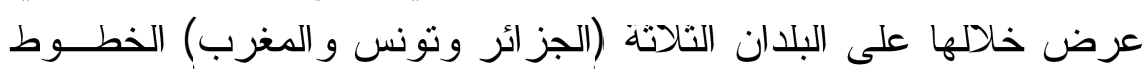
الكبرى لمشروع الشرق الاوسط الكبير، و استاتز موضوع ونو الإصــلاحات 
السياسية بحصة الاسد من المحادتات التي اجر اها مع الرؤساء بوتقليقــة

وبن علي ومحمد السادس على حساب القضايا الدولبة الساخنة|(1).

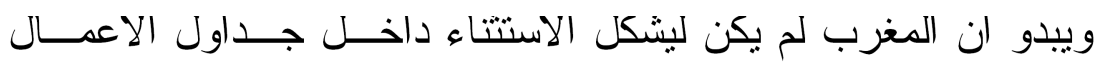
(Agenda)

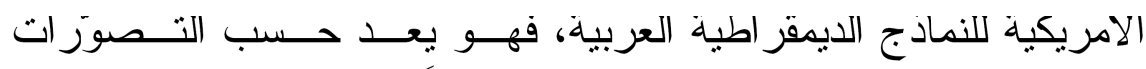

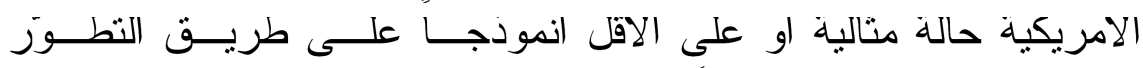

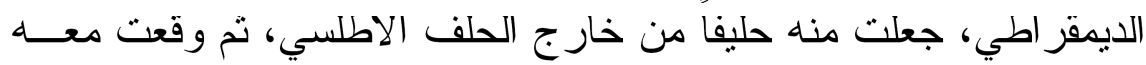

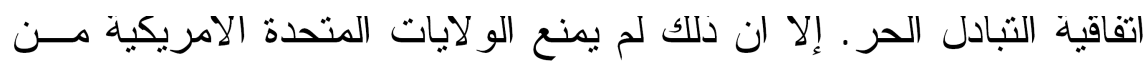

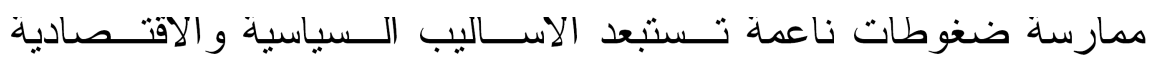

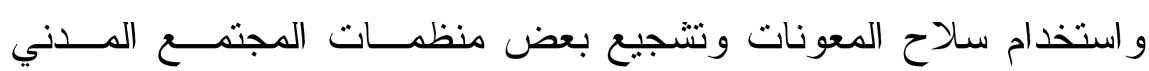

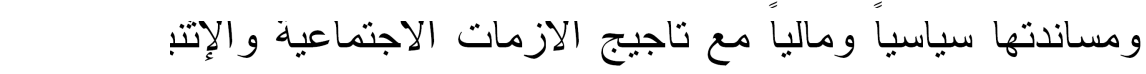

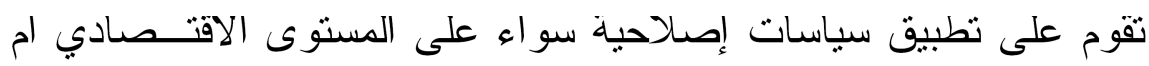

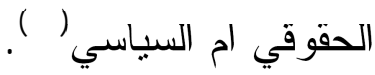
ومن ثم بمكن رصد دعامنين حكمتا استجابة النظام السياسي المغربي

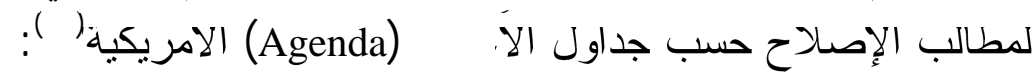

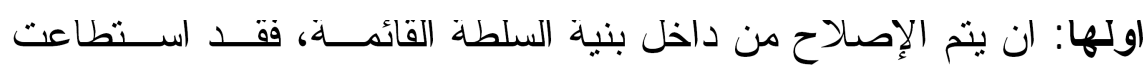

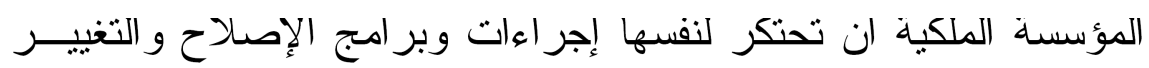
وتتفي اي دور فاعل او مؤثر للقوى الاخرى في المجتمع. فهي إصلاحات

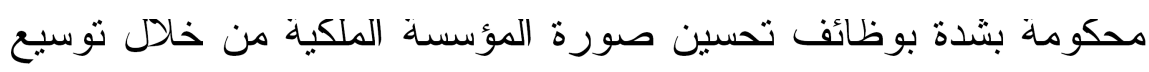
مجال الحريات السياسية و الفردية دون محاولة تغبير البنية الفعلية للسلطة.

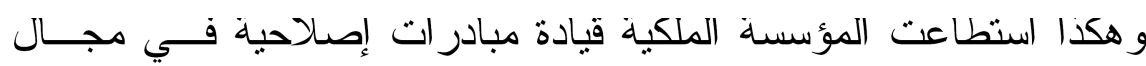

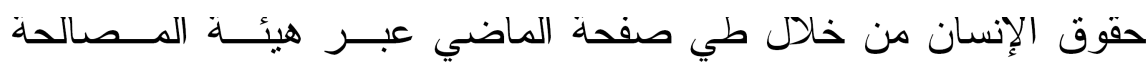

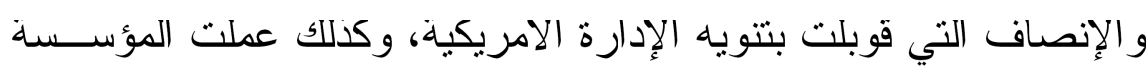

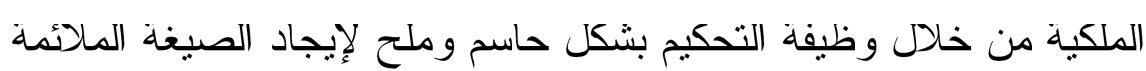
لمعالجة التعددية الفكرية و العقبدية المرتبطة بمدونة الاسرة. 
شانهما: ان يكون إصلاحا تدريجيا، يتجنب الارتدادات المحتملة لخطوات

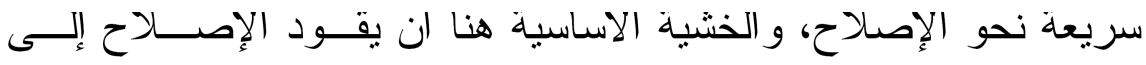

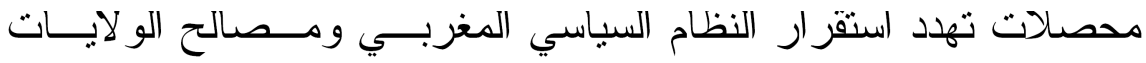
المتحدة على السو اء، من قبيل ان يصعد إلى السلطة إسلاميون قد لا تكون

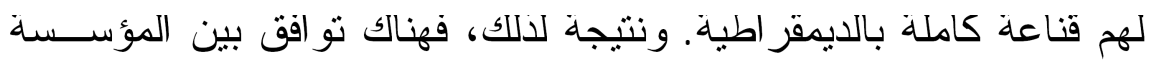

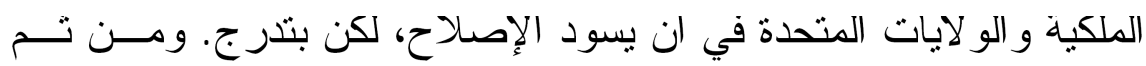

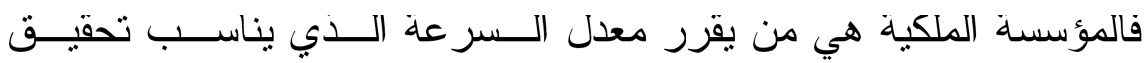
الإصلاح على اساس النطور السياسي و الاجتماعي و الثقافي. ثالثا - رؤيه المؤسسه الملكيه و المعارضه للإصلاح السبيسي

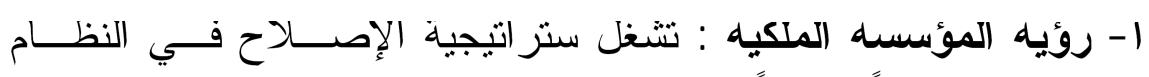

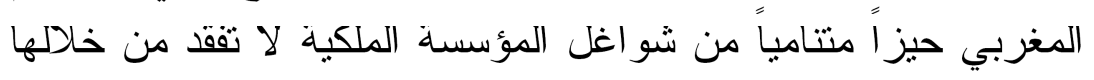

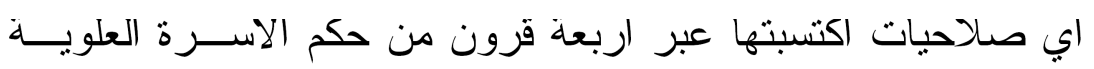

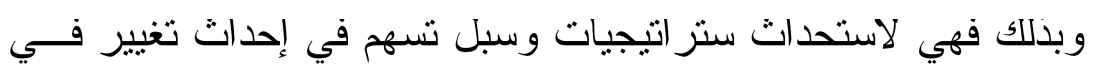

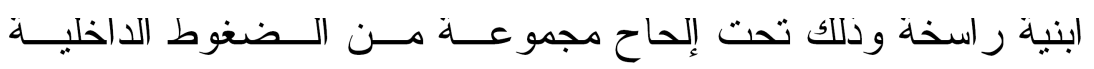

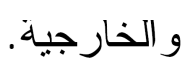
هذا وقد تبدت ضرورة الإصـالح اثز تز اكم مجموعـــة مــن التحــديات

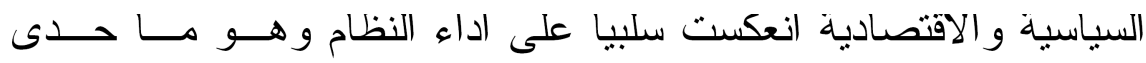

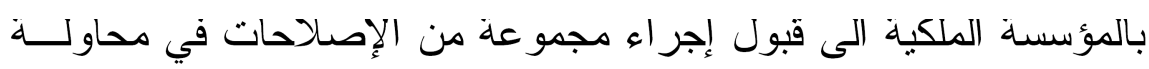

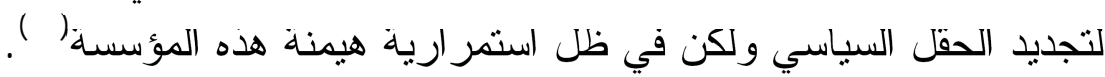

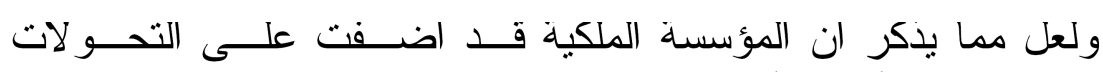

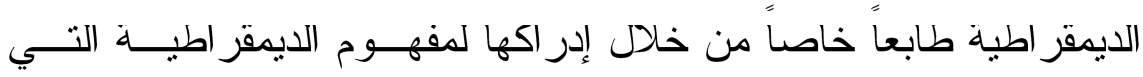

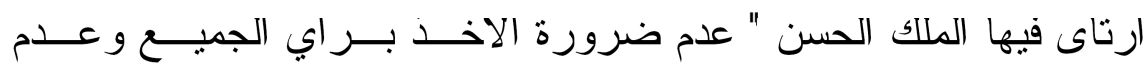

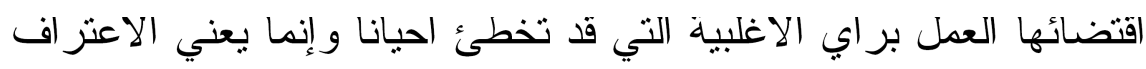
بصو اب راي الاغلبية وتبني رايها"(rاب). 
و على الصعيد نفسه حرص العاهل المغربي على المبــادرة بتحقبــق

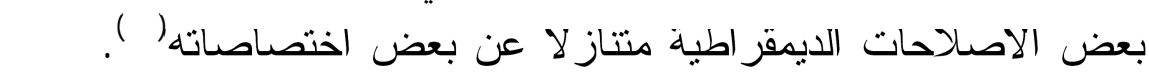

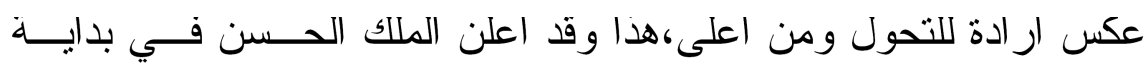

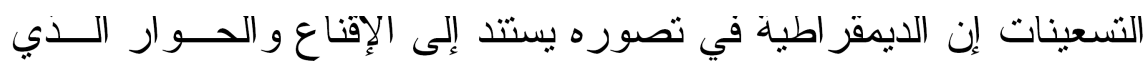

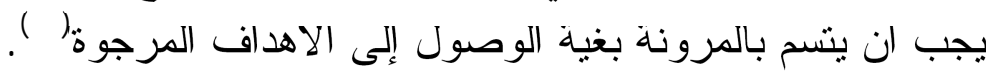

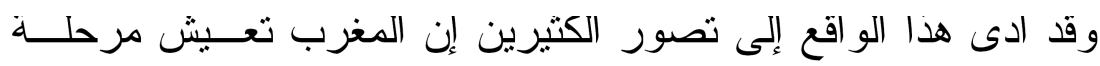

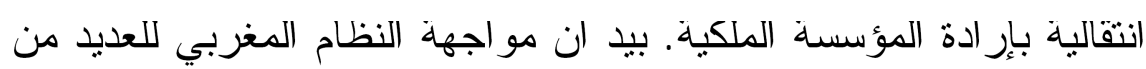

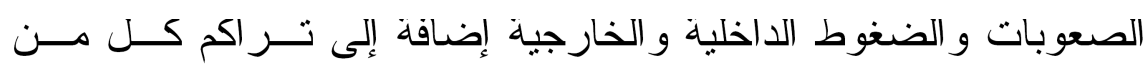

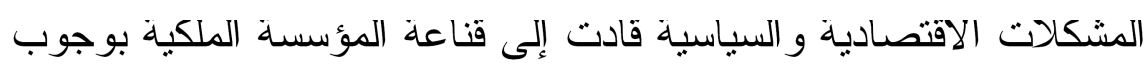
الإصلاح وتحديد الحقل السياسي بما لايمس محورية دورهــــا بحسبسانها

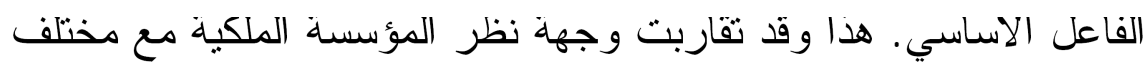

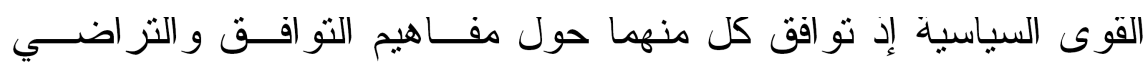

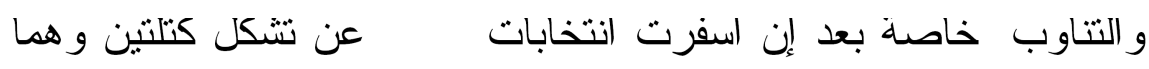
الكتلة الوطنية و الوفاق الوطني بمثنابة انعكاس لنوع من التنائية الــسياسية في المغرب.

وفي إطار هذا السياق عدت التغييز التي اعلن عنها النظام بمتابة الية

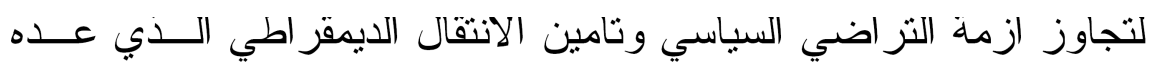
العاهل المغربي زهينا بتحقيق التناوب السياسي. و على هذا النحو ارنبطت رؤية المؤسسة الملكية للتحو لات الديمقر اطية

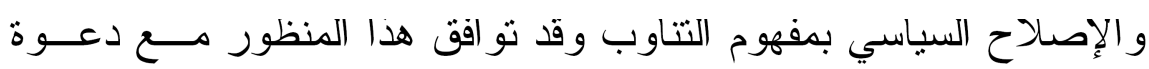

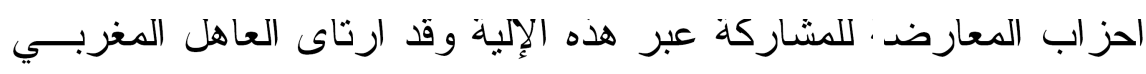

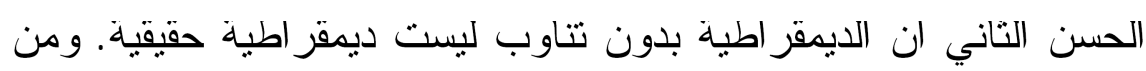

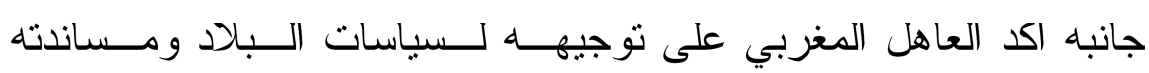
للحكو مة (ro) 
ولعل مما يذكر ان العاهل المغربي حرص على استخدام كلمة تتــاوب السلطة ولبس تداولها كاحد اليات التغيير الذي ارتاى فيها اكثر تعبير ا عن

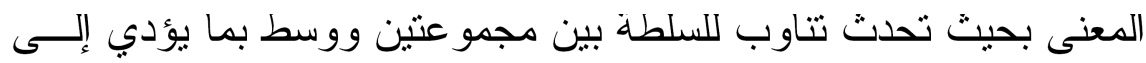
التجديد المستمر من خلال التراضي على هذا النحو بعكس التتاوب نغييرا في الاشخاص وليس في التوجه السياسي و التغيير في اساليب الحكومة.

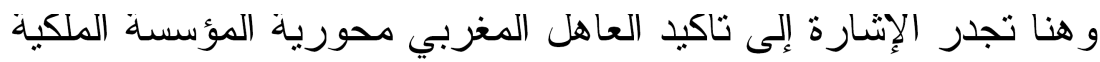

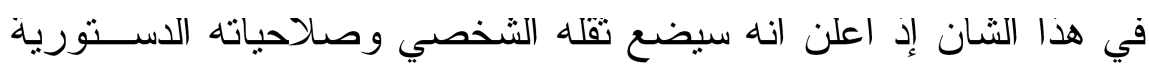
لضمان نز اهة الانتخابات (ب7). وهنا تجدر الإشارة إلى ان المفاوضات التي شهدنها البادد بين كل من

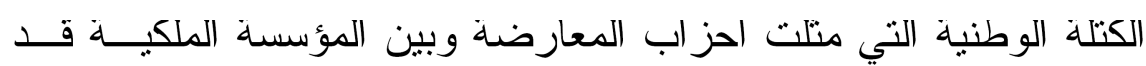

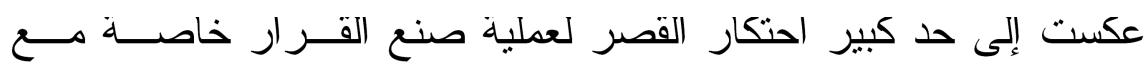
الغموض العقبدي لاحز اب المعارضة.

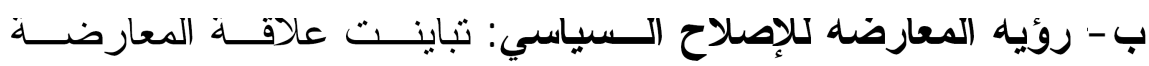

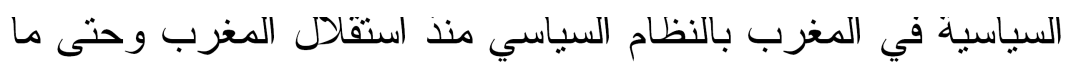

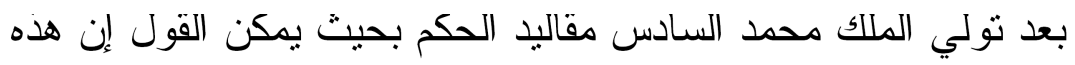

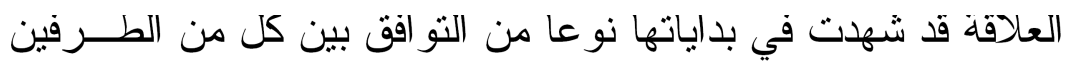

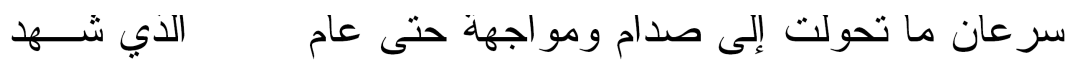

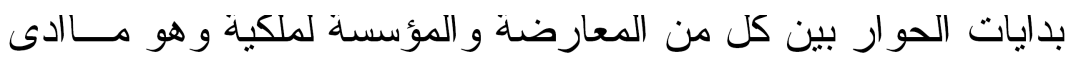

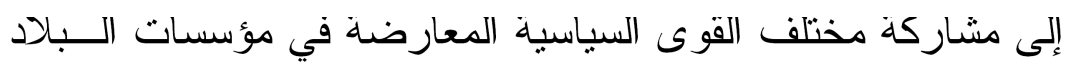
حتى تمكنت المعارضة من ادارة السلطة التنفيذية. هذا وقد شهد عام تغير ا ملحوظا في خطاب المعارضة الر سمية

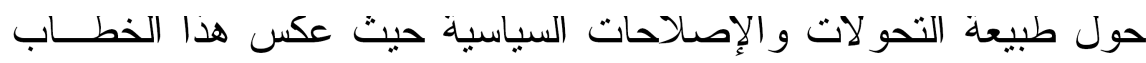

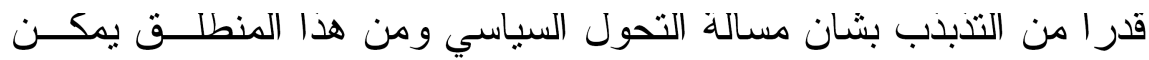

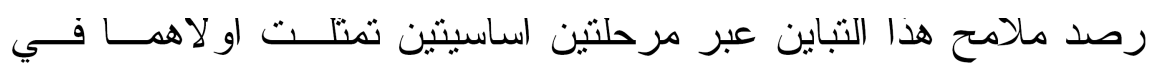


التوكيد على ضرورة الإصـاحح و التغيير في حين تبدت الثانية عبر مرحلة تقبل الإصداحات الشكلية و الاكتقاء بالمشاركة في الحكومة.

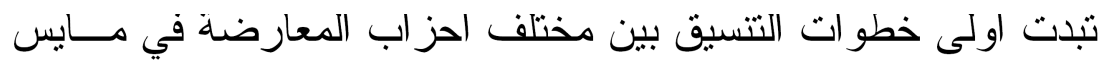

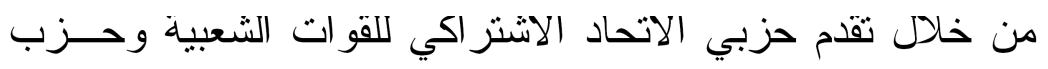

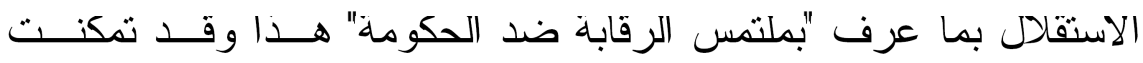

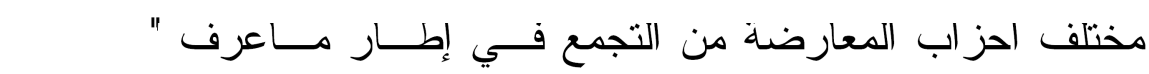

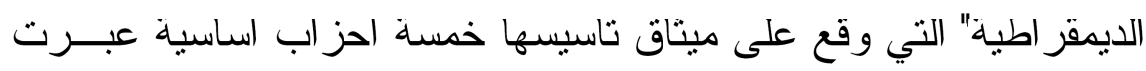

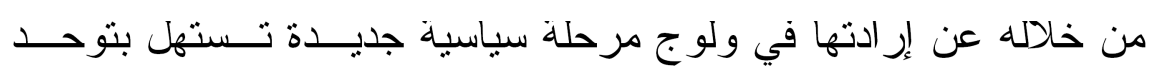

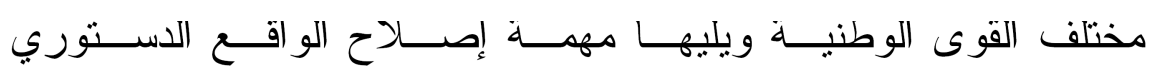
و السياسي (rV)

إلا انه برغم هذا التتسيق إلا ان إطر اف الكتلة الوطنية افتقرت إلـى مئى

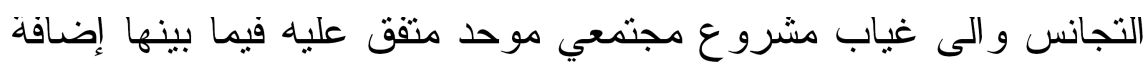
إلى عدم تمسكها ببرنامج ورؤية مشتركة.

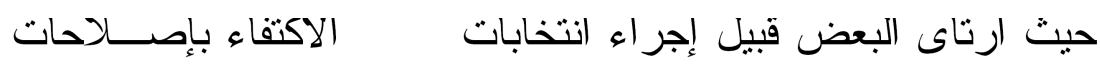

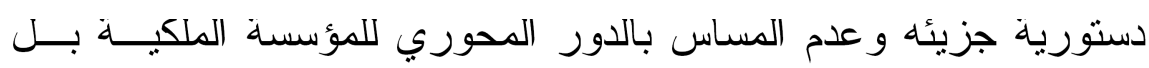

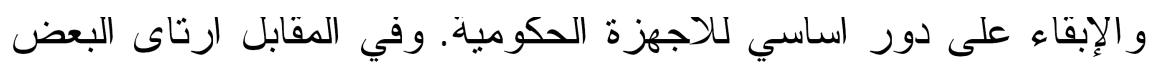

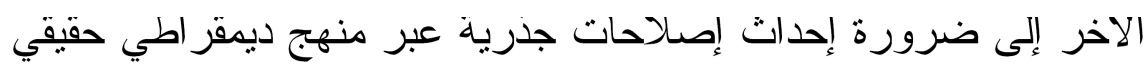

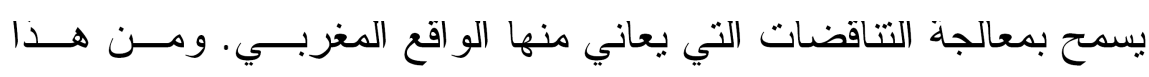

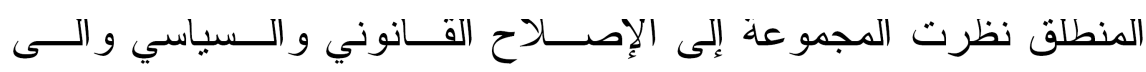
التحو لات الديمقر اطية بصفة عامة باعتبار ها جزء لا يتجز ا ومطلب شعبي الإني وتوجه عالمي يصعب إغفاله (rN).

وقد عكس هذا الو اقع بطبيعة الحال تتاقضـا حادا في كل مــن خطــــاب إعله

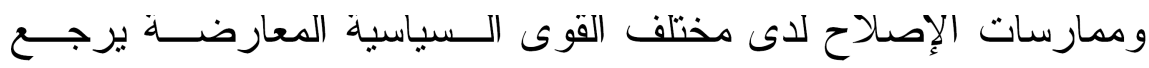

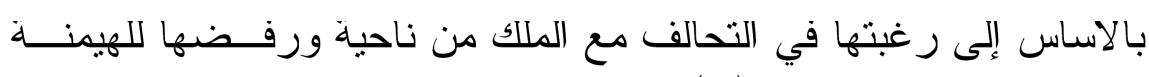

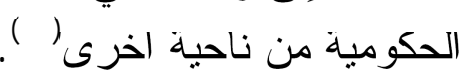


وبعامة يمكن القول إن مختلف القوى السياسية المغربية قد هدفت من هذا الإصلاح إلى بناء ملكية دستورية شبه رئاسية تحتفظ المؤسسة الملكية

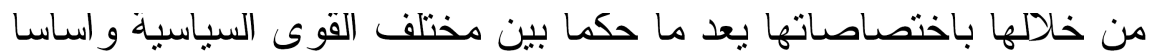
لوحدة التز اب المغربي و لاستقرار و امن البلاد مع تعيين الملــك لــــئيس الوزر اء من الاغلبية البرلمانية.

\section{رابعا - ملامتح الإصلاح الاستوري في المغرب}

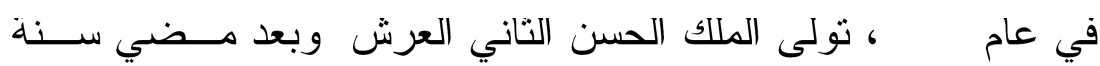
ونيف على توليه للعرش، تمت المصادقة على الدستور المغربــي الاول، وخئ

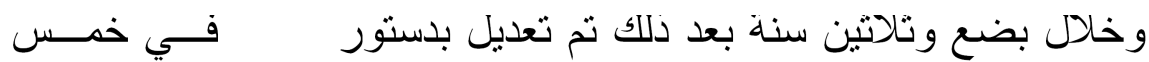

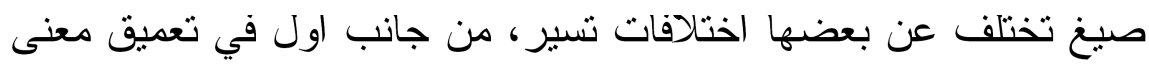

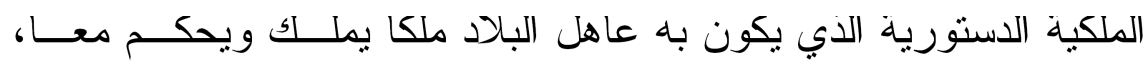
ويمضي، من جانب ثنان، في التاكيد على قاعدة الحريات العامـــة، وفــي لئهي

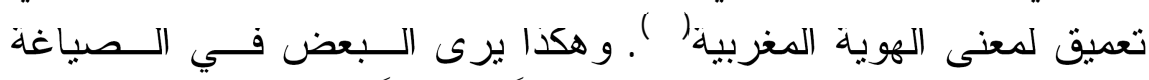

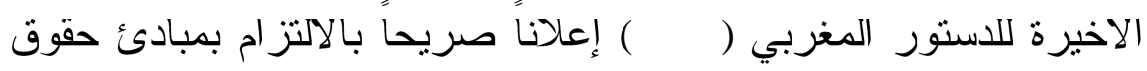

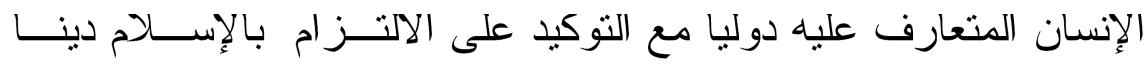

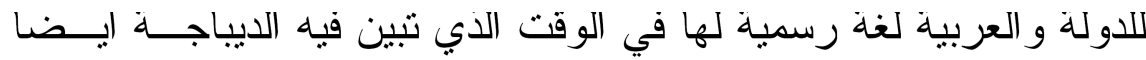

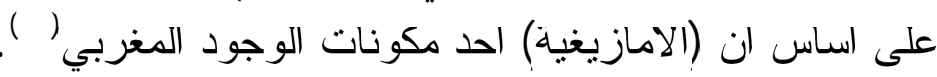

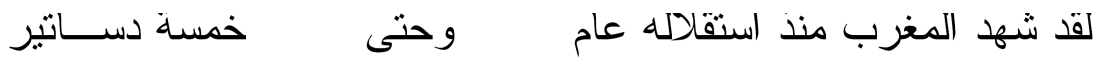

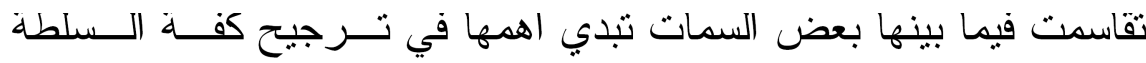

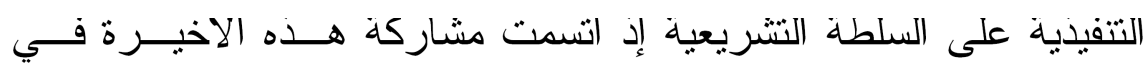

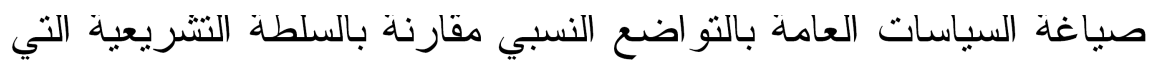

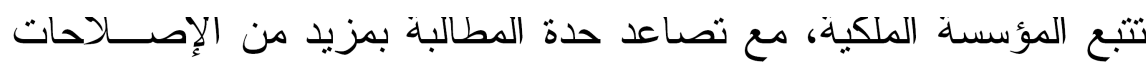

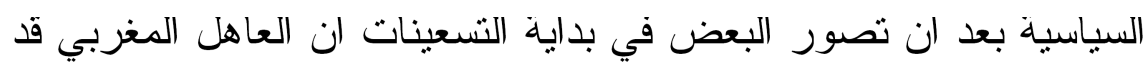
عزى التحو لات الديمقر اطية في سعيها نحو الإصدلاح و التغيير إد قـدمت بـديه 
المعارضنة المغربية للعاهل المغربي تلاتة مذكر ات تتــضمن تـصور اتها

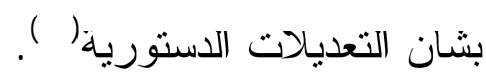

هنا تجدر الإشارة - على نحو مابينا سلفا - ان هذه الاخبرة قد عكست محاولة مختلف القوى السياسية إيجاد نو ازن بين كل من السلطتين التنفيذية

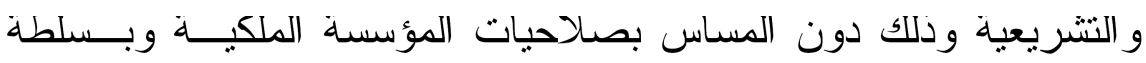

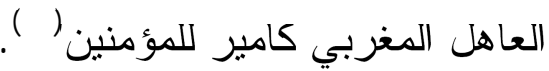

على هذا النحو يمكن القول إن تعديالت

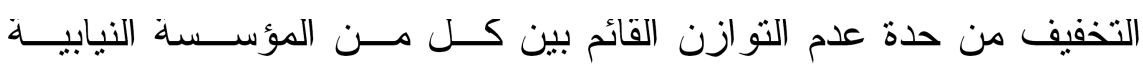

$$
\text { و الحكومية. }
$$

ودلك من خلال إعطاء المزيد من التقل للسلطة النشريعية مع توسـيع إيع

$$
\text { صلخحيات رئيس الوزر اء. }
$$

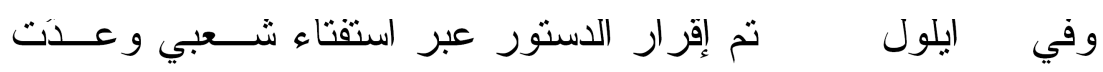

التعديلات التي ادرجت على دستور بمثابة نقطة تحول استاسية في

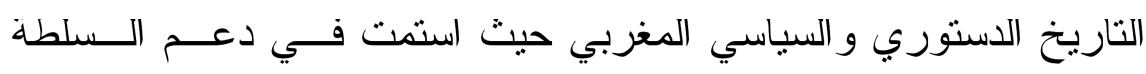

التشريعية وحددت دور الحكومة في العدبد من المجالات. ونظرة فاحصة

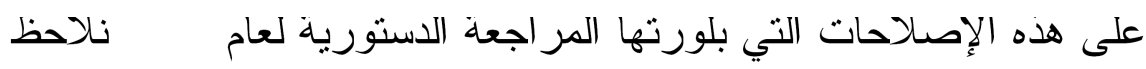

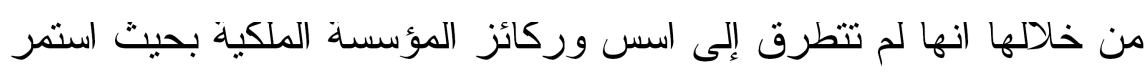
احتكار هذه الا خيرة للحقل السياسي (عَّ).

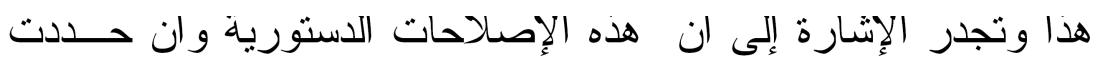

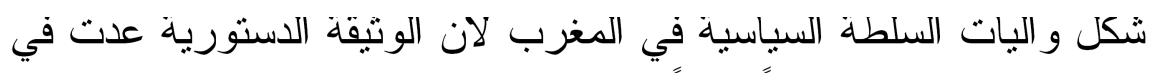

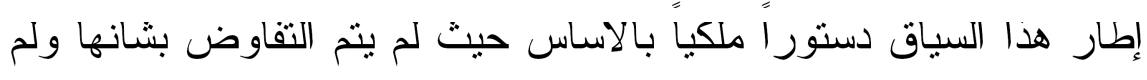

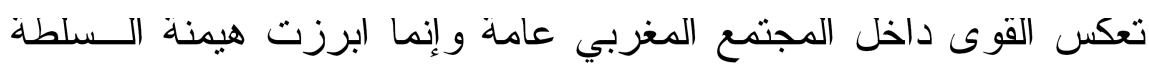
الملكية في إطار التو ازن القائم (ro).

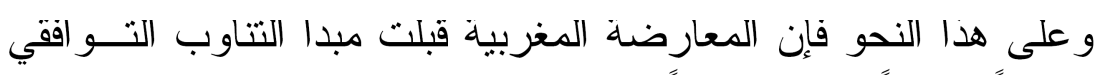
يعده اتفاقاً سياسياً وليس استتاداً إلى الدستور . 
وهو ما يشير في مجمله إلى انه برغم الإصلاحات الدستورية التـي التي التئي

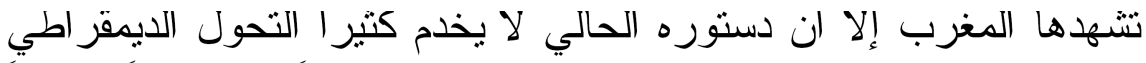

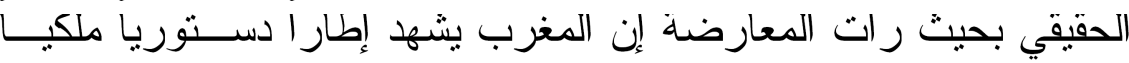

$$
\text { وليس دستورية حقيقة، ودلك لان: }
$$

- التعديلات الدستورية في المجال الحكومي اتسمت بالتو اضنع النـسبي نتيجة لاستمر ار طبيعة بقاء العلاقة بين كل من المؤسـسـة الملكيــة بـاسة

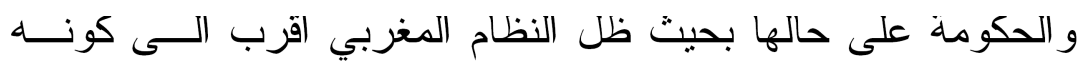

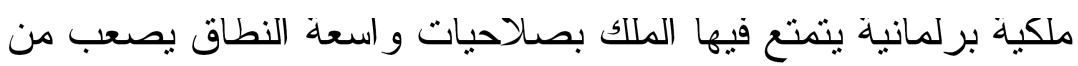
خلالها تصور قبول هذا الاخير لوزر اء لا ير غب في تعبينهم.

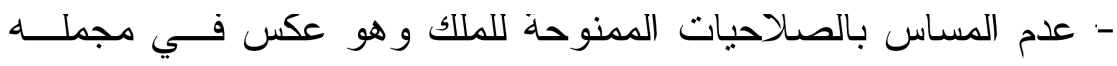
الطابع السياسي لا الدستوري لهذه الإصلاحات.

\section{خالمسا: ملامتح التحول الديمقر اطي في المغرب}

ا - التعدديه (لحزبيه

لقد عرف المغرب عقب الاستقلال حياة سياسية صاخبة و غنية، شكلت

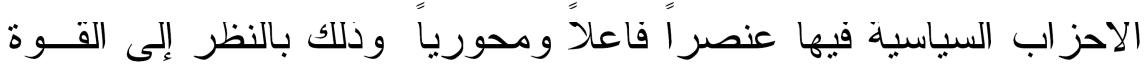

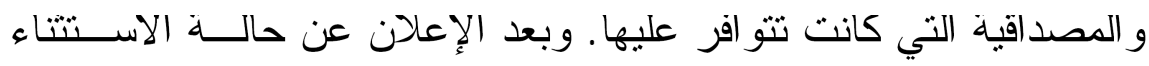
سنة ، طال الاحز اب السياسية التهميش و الإقصاء من الحياة العامة الإنة دام إلى حدود انطلاق المسلسل الديمقر اطي، إلا انه منذ مطلع التمانينات، اخذ الضعف و الوهن بدب في الهيكل الحزبي المغربي. ويضم المغرب رزبا سياسبا منباينة الاتجاهات، وتتفاوت من حيث

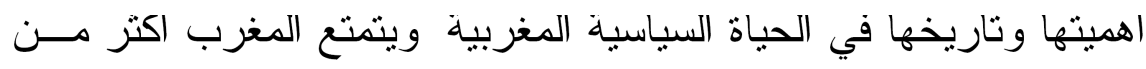

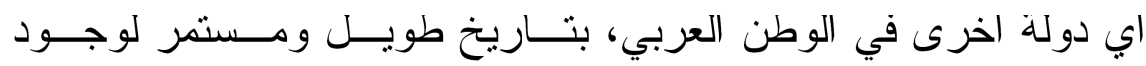

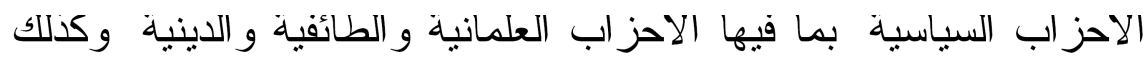

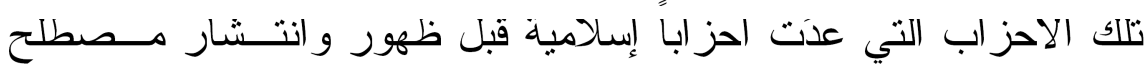


الاحز اب السياسية الجديد.ومع ان المغرب ظل منذ استقلاله فــي عــام

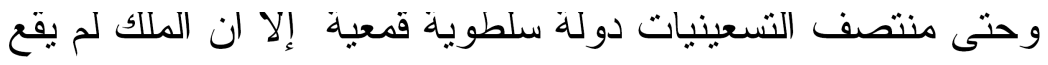

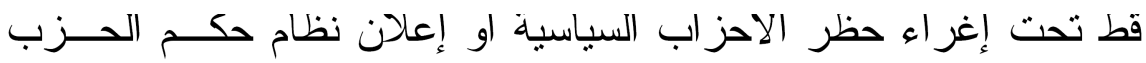
الو احد. ونتيجة ذلك التقلبد، فإن بعض الاهراء الاحز اب السياسية المغربية مستمرة

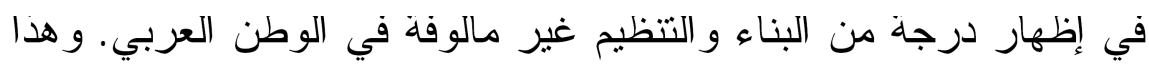

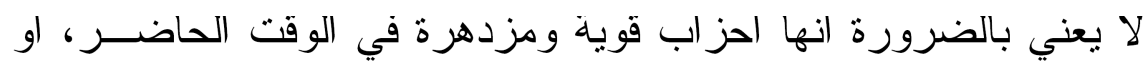

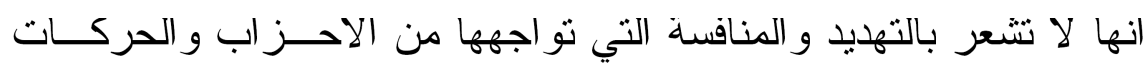

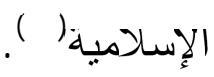

ومن العيوب التي تسيء إلى التعددية الحزبية المغربية هـــي تقــاقم

النزعة الانقسامية داخل الاحز اب السياسية التي لا يوجد مايسو غها، سوى التعيه

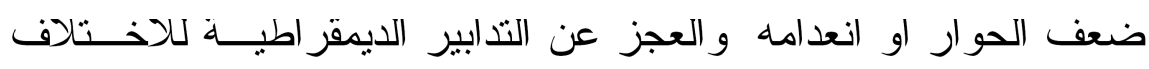

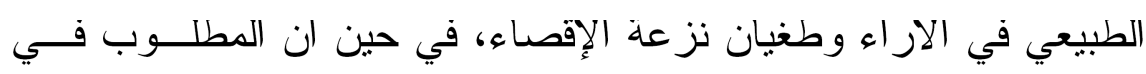

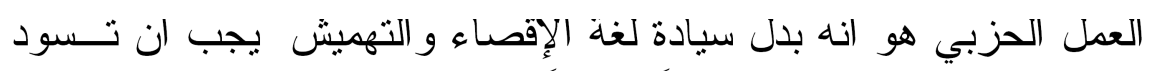

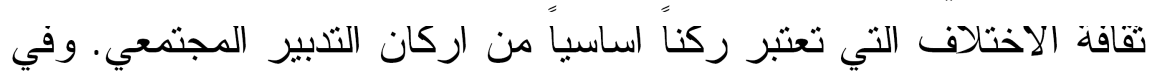

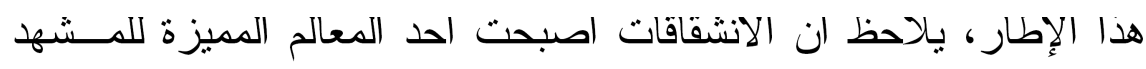
الحزبي المغربي، وهو الامر الذي اسهم في إضفاء المزيد من حالة عـــدم الاستقر ار داخل النظام السياسي المغربي، و إذا بحتنا في الخلفيات المغدية

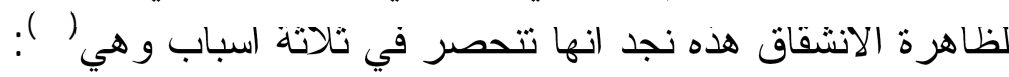
• الانشقاقات ذات النز عة الانفصاف هذه نجالية.

$$
\text { ه الانشقاقات الحزبية المدبرة. }
$$

$$
\text { الانشقاقات ذات المرجعية الانقسامية. }
$$

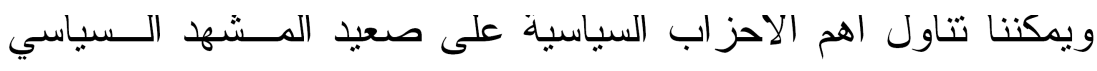

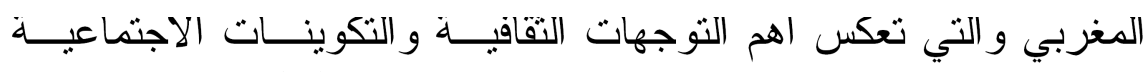

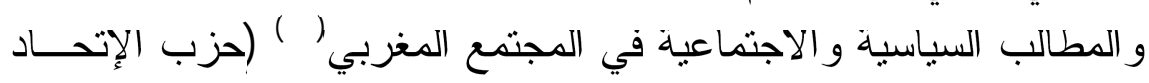

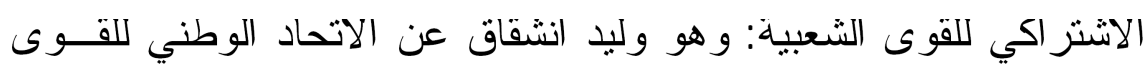




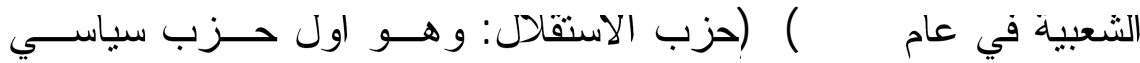

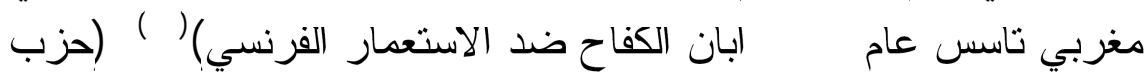

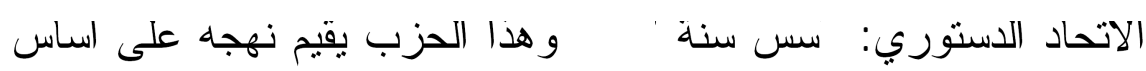
من المحافظة على التقالبد الدستورية للدولة على محورية دور الملك الامر

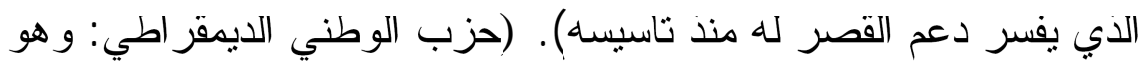

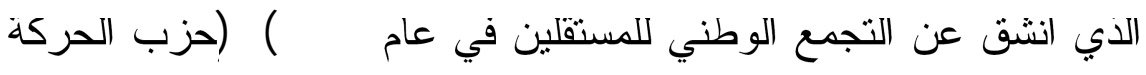

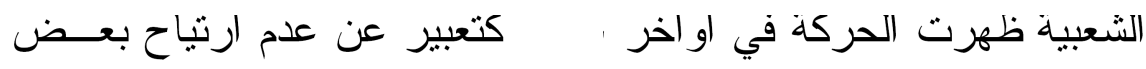

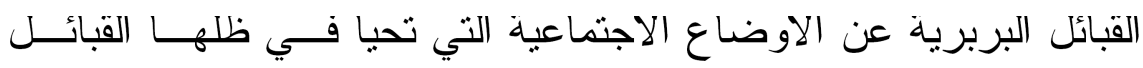

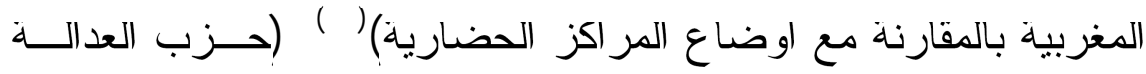
و التتمية وهو حزب ديني سياسي إصلاحي دات مرجعية دينية يستتد إلى بلى

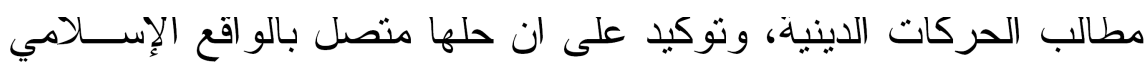

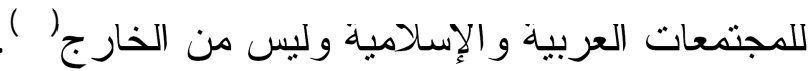

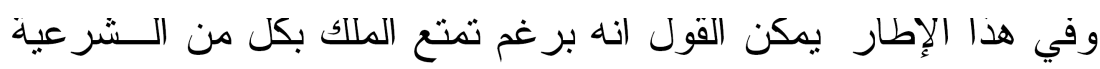

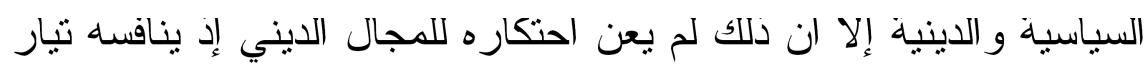

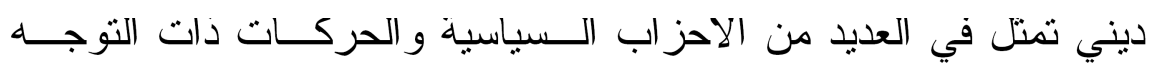
الإسالمي الديني، و التي انتشرت في ارجاء المغرب مشككة في الثرعية الدينية للنظام السياسي إلا انها لم تمئل باي حال من الاحو ال بديلاً سياسيًا للنظام الحاكم.

إن الجديد في هذه الاحز اب انها ر اكمت تاييدا شعبيا قويا، مستغلة حالة

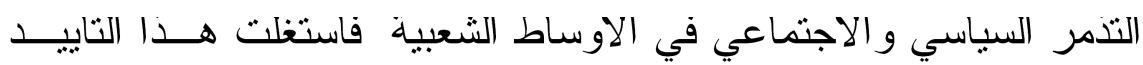

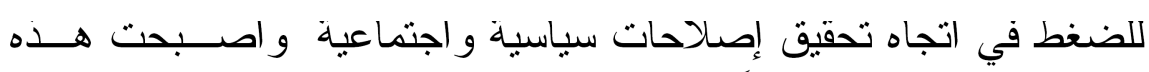

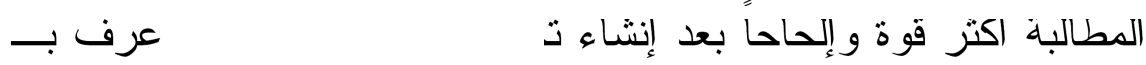

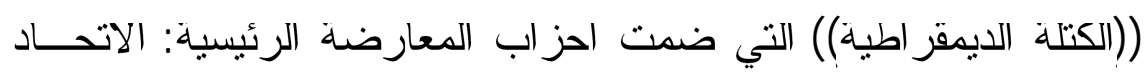

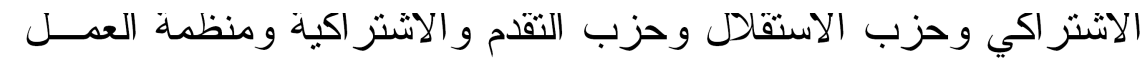


وساهم هذا التجمع إلى حد كبير في صوع مطالب موحــدة تعبـر عـنـ

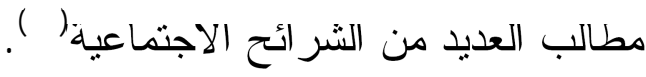

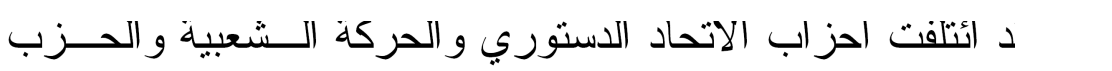

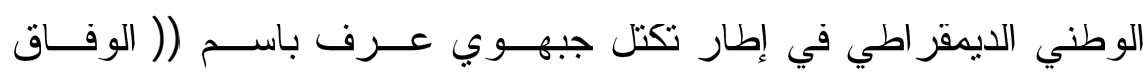

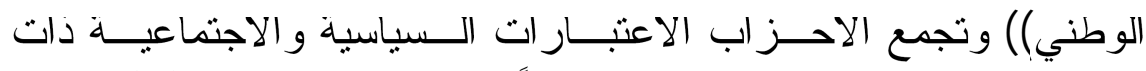
الخصوصية المحلية و المقصود بها اساساً ((الهوية الامازيغية))(باعل.

\section{ب - الإسلام السياسي في المغرب}

برغم تمتع الملك بكل الشرعية السياسية و الدينية الا ان ذلك لم يعـن

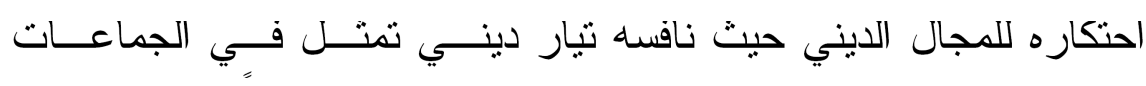

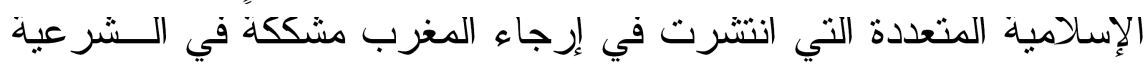

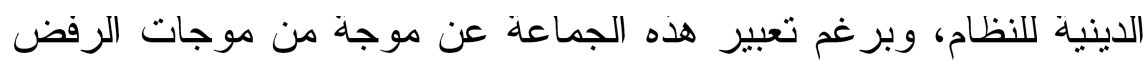
للنظام السياسي إلا انها لم تمثل باي حال من الاحو ال بديلا سياسيا للنظام الحاكم (ع) . (ع)

و على الرغم من صفة الضعف الني يجمع عليها الدارسين ونؤكــدها

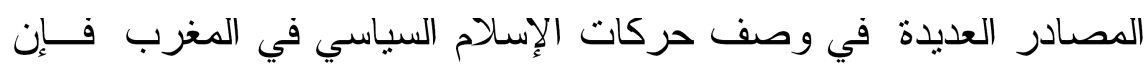

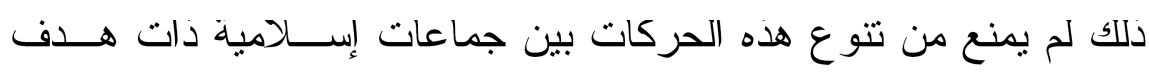

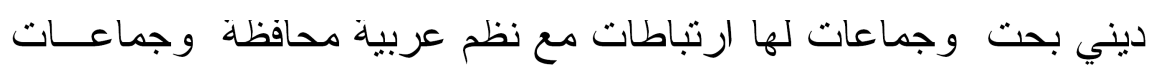

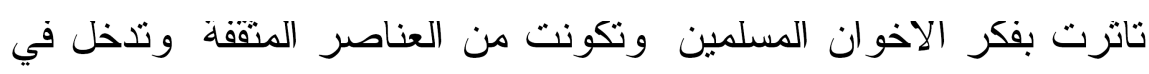

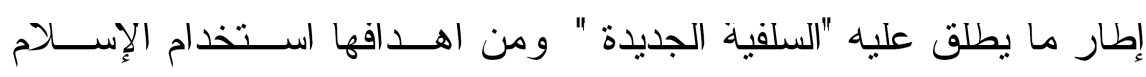

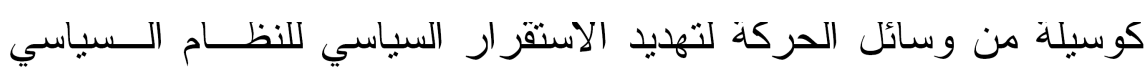

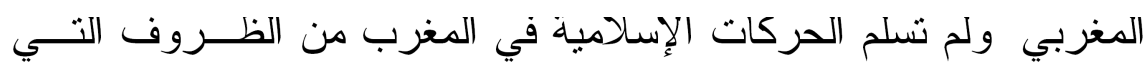

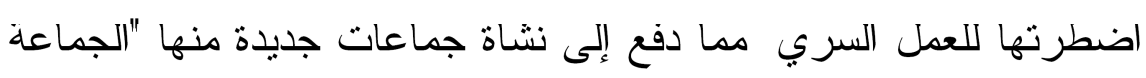

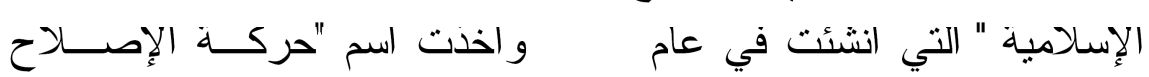

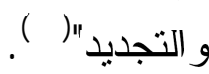


وتز اوحت علاقة المؤسسة الملكية و الجماعات الإسلامية بـين تـلاث

$$
\text { دوائر: }
$$

- دائرة الإدماج الجزئي: وتجسده علاقة المؤسسة الملكية بحركة التوحيد

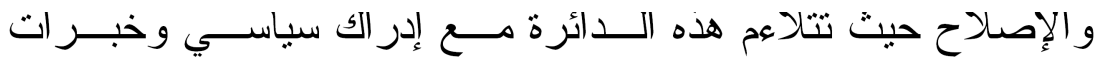

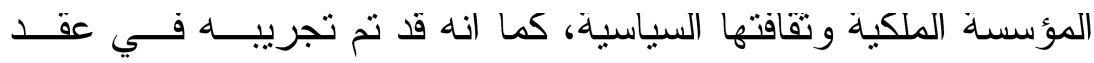

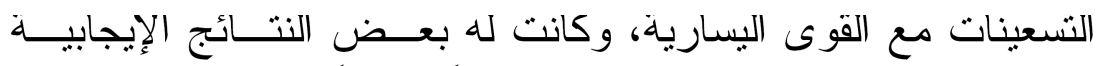

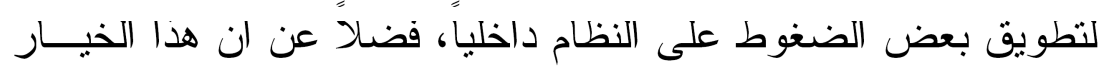

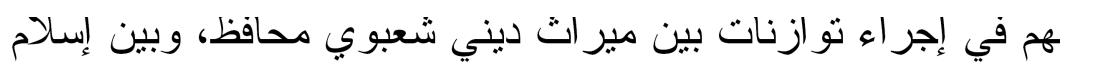

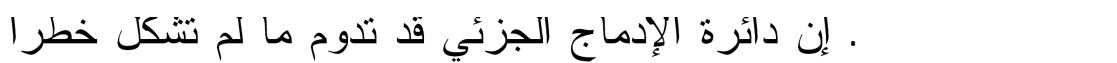

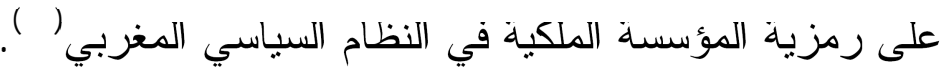

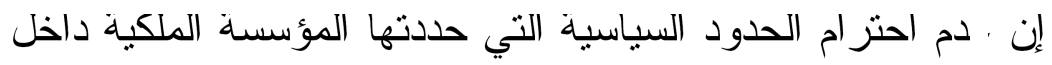

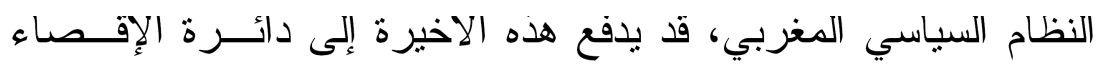
الجزئي، فهذه الدائرة محددة بشروط سياسية.

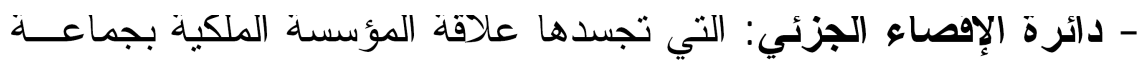
العدل و الإحسان، لا تز غب في الاستبعاد الكلي لجماعة العدل و الإحسان لاكتر من هذا المستوى، خشية حدوث مشكلات جانبية اخرى، قد تؤثر

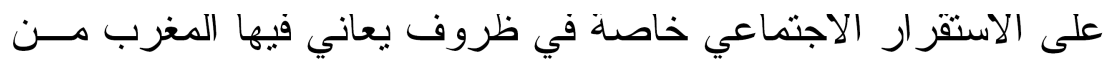
اكثر من مشكلة و ازمة على المستوى الاجتماعي السياسي و الاقتصادي.

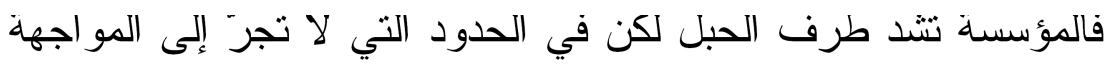

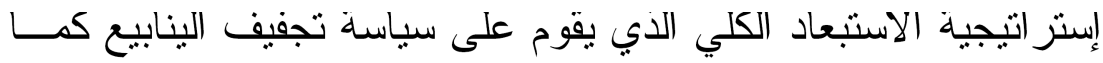
حصل مع الجماعات الجهادية السلفية وفي الوقت نفسه لا نترك المجال

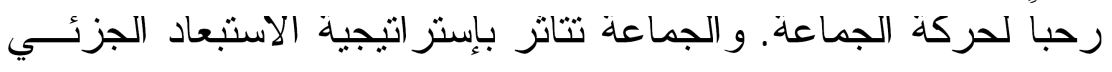
في الحدود الني لا تتزلق إلى العنف و لا تقبل بالمشاركة السياسية وفق إلقن القو اعد القائمة. 
ويمكن إجمال عناصر هذه الدائرة في عدم نفــي جماعـــة العــدل

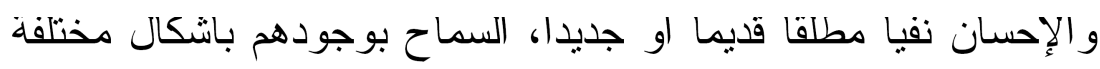

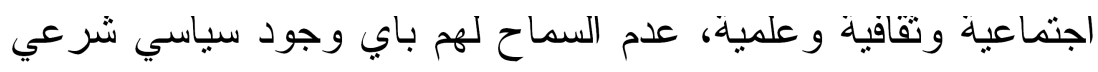

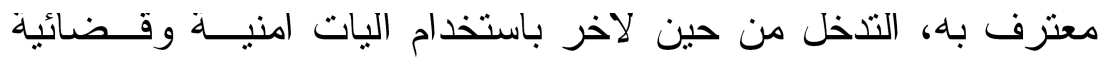
لتحجيم نفوذهم.

- دائرة الاستبعاد الكلـي: وتجسدها علاقة المؤسسة الملكية بالجماعــات

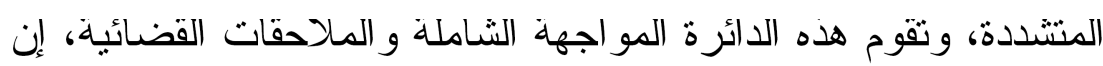

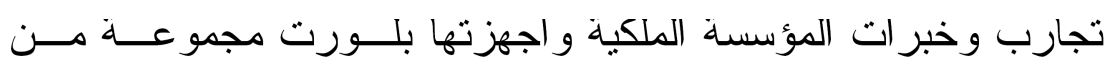

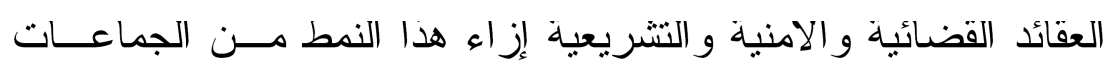

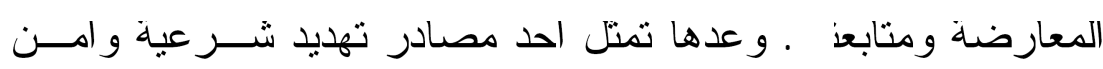
و استقر ار النظام السياسي.

\section{ج - المر اة والتحول الديمقر (طي}

يعود ارتقاء المر اة المغربية إلى المؤسسة التشريعية منــــ التـسعينات

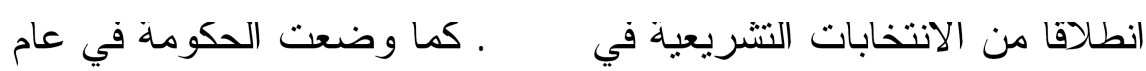

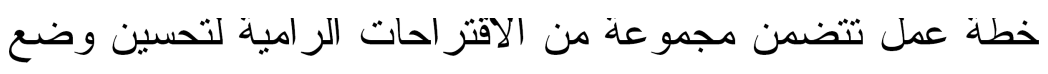

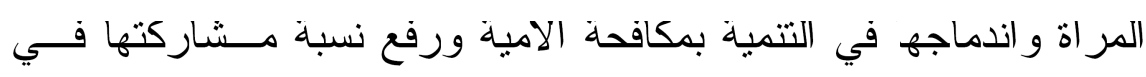
الحياة السياسية.غير ان الخطة اتارت معارضة وزير الاوقاف ورؤســاء المجالس العلمبة وحزب العدالة و التتمية. (عV). و إذا كانت الحركة النسائية قد كتقت من تحركاتها في السنوات الاخيرة لتوسيع وتطوير هذه المشاركة بشكل اكثر الهمية من خلال توسيع اللائحة

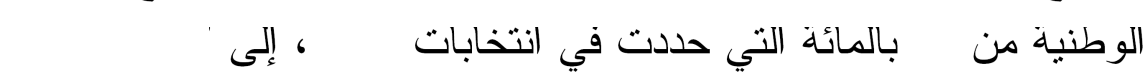

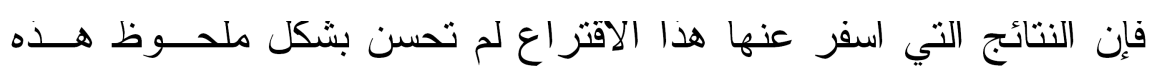

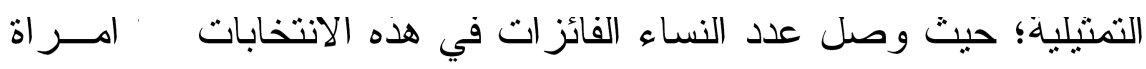
من مجموع وبخاصة وان اللائحة ظلت مقتصرة على امر اة اي 


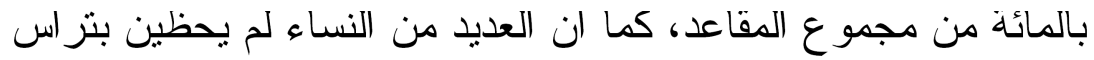

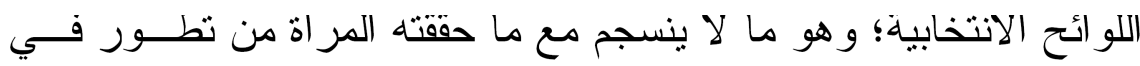
عدة مجالات سياسية و علمية و عملية (ع).

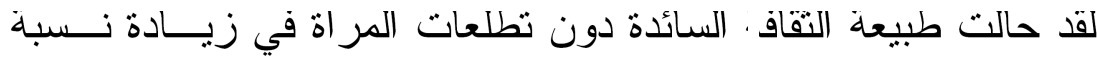
المشاركة في العمل السياسي كما اصطدمت هذه النطلعات بممارسة حزبية

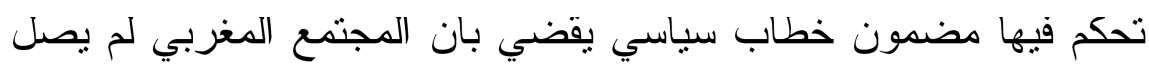

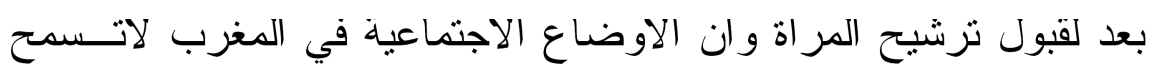
بذلك (ع9)

و على ذلك تظل نسب نزشيح المر اة محدودة، امـا نسب الناجحات فــالح تكاد تذكر (0)، ومع دلك فإن وصول المراة للبرلمان هو من قبيل النطور الايجابي على صعيد التحول الديمقر اطي في المغرب، و إن كانت المحادير لاتز ال تكتتف سبله.

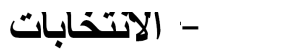

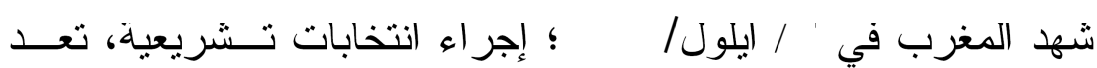

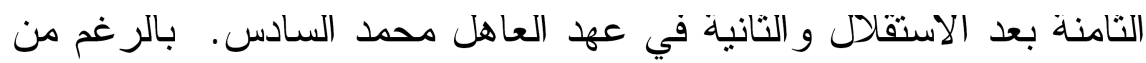
الانتخابات يمكن استتناج الاتي (0i):

ان النظام الانتخابي المعتمد في المغرب منذ تجربة انتخابات ع · . r،

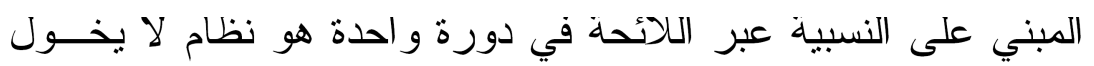

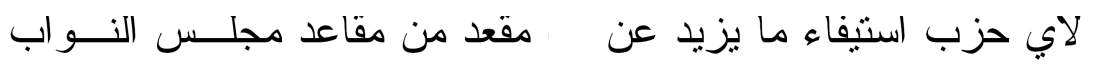

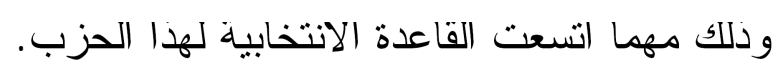

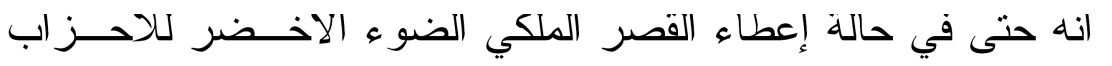
الفائزة في الانتخابات الجارية لإحداث تحالفات من اجل إنشاء اغلبيات

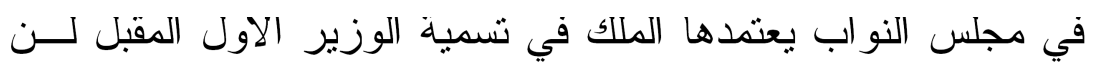


يكون في وسع هذا الوزير الاول اقتر اح سوى لائحة الوزراء الــذين يبقى للملك وحده الحق في قبولها او طلب تعديلها.

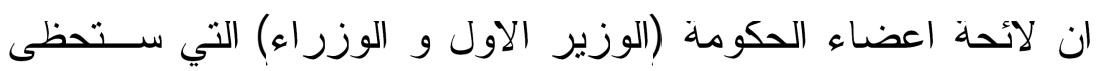

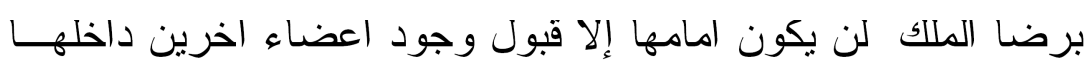
(وزر اء) غالباً ما بسمون وزر اء سيادة حزبيين او تقنوقر اطبين.

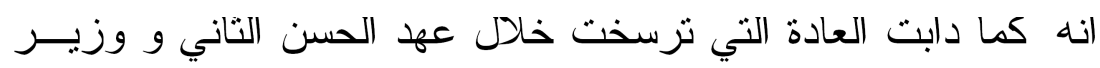
داخليته المتوفى إدريس البصري، يبادر الملك إلى تعبين كتاب عامين

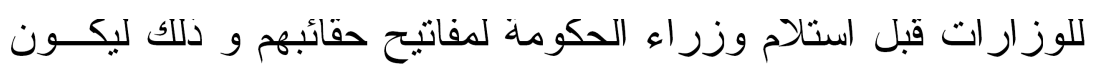
هؤ لاء الوزر اء رهائن لدى اولئك الكتاب العامين.

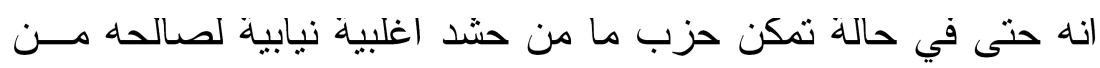

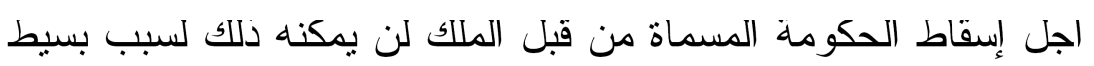

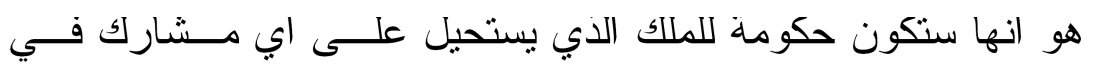
البرلمان محاولة القيام بمعاكسة المشيئة الملكية.

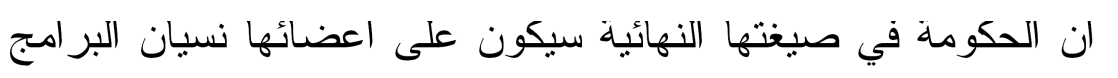

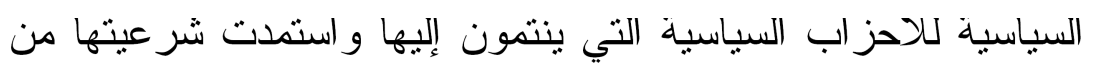

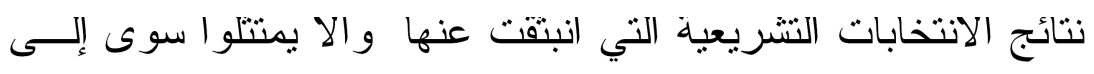
البرنامج الحكومي الذي سيوصيهم الملك بالعمل على تتفيذه.

\section{و - الإصلاح السياسي في العهد الجديل(Or)}

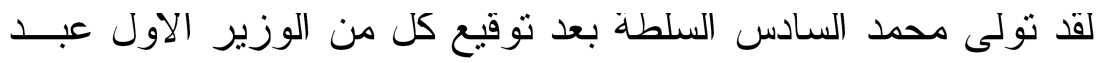

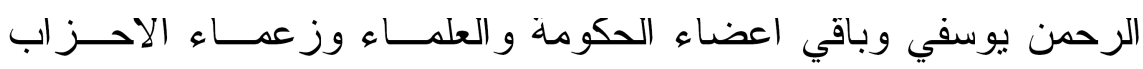
و غير هم من الشخصيات ودلك في إطار الالتز ام بالطابع التقليدي للنظـــام الذي يؤكد سمو المؤسسة الملكية على بقية الفاعلين السياسيين. ومن جانبه

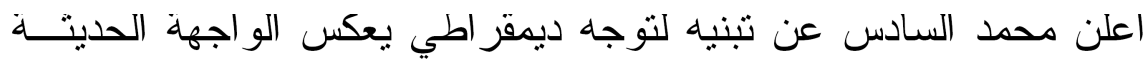

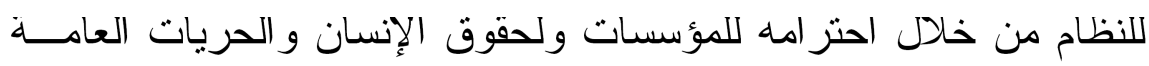


وتحديث مختلف البني الاقتصادية و السياسية و الاجتماعية مع عدم إغفــال ركائز الو اجهة التقليدية للنظام المغربي.

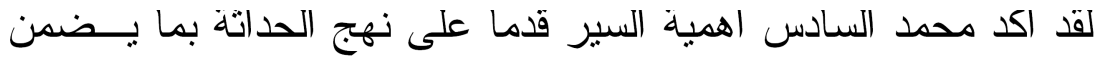

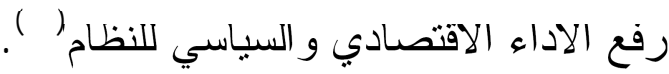
وقد بادر بالفعل باتخاذ مجموعة من الإجر اءات التي كان من شـــــانها

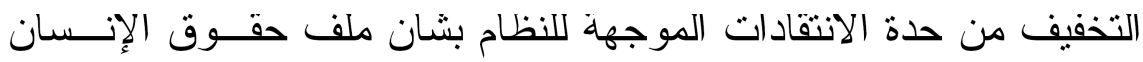

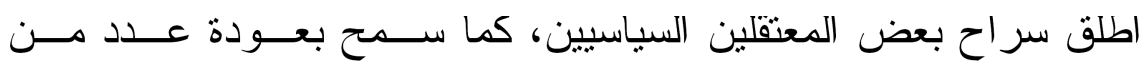

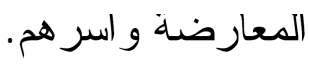

كما حرص العاهل المغربي في محاولة غير مسبوقة بتحجيم سـلطات

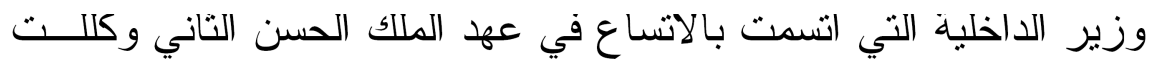
هده المحاو لات بإقالته ودلك نتيجة لعدد من التجاوزات التي اتهم بـشـانها

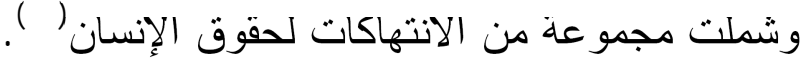

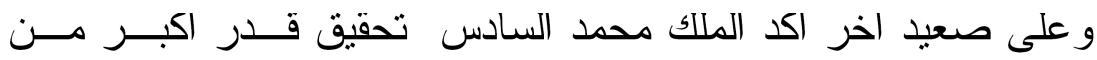
التو اصل مع الجماهير وتحقيق تصـالح مع مو اطني العديد مـــن المنـــاطق

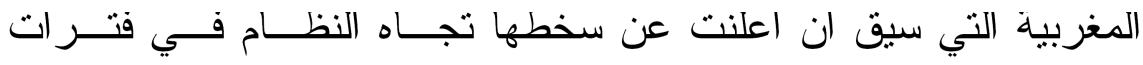
سابقة،هذا كما لم يغفل الملك محمد السادس اهمية محاربة الفقر ومسـشكلة انعدام و العدالة التوزيعية وفتح ملف التعليم من خلال إنشاء لجنة عهد إليها

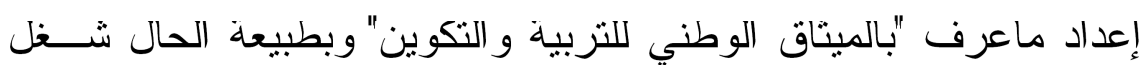
ملف الإصلاح السياسي قمة هذه التحديات التي تشهدها العهد الجديد.

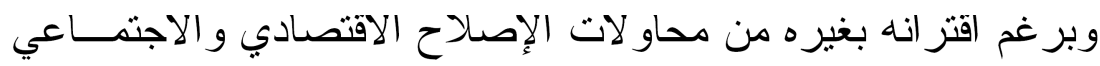
نتيجة صعوبة الفصل فيما بينهم إلا ان الملك محمد السادس اولى لإهلى اهتماما

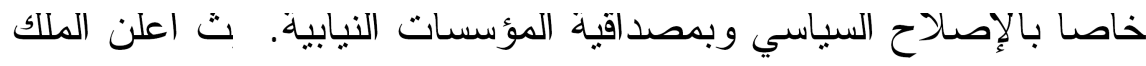
محمد السادس خطابه في / / / عن إصلاح عميق للاستور لتعزيز الديمقر اطية (00). جاء بعد سلسلة من المظاهر ات و المسيرات التي شهدنها

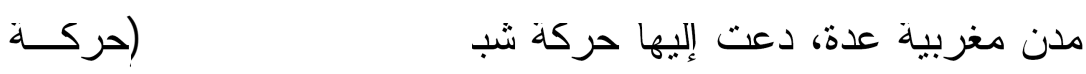


شباط). حيث كان من ابرز مطالــب هــذه المـسـير ات(إقــر ار دســتور

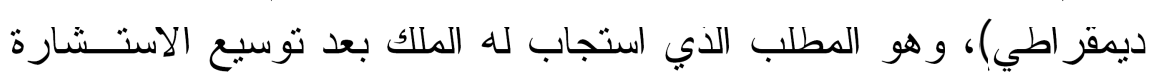
مع مختلف الفعاليات السياسية و الحزبية و النقابية وكذا الشبابية.

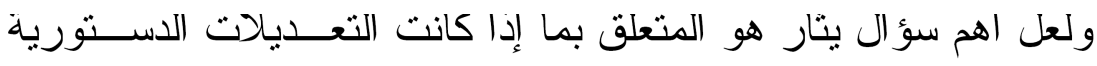

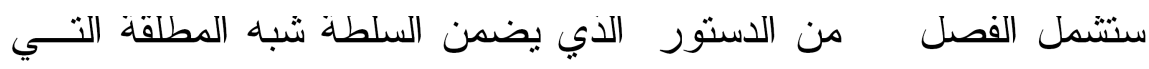

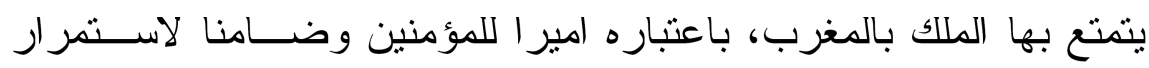

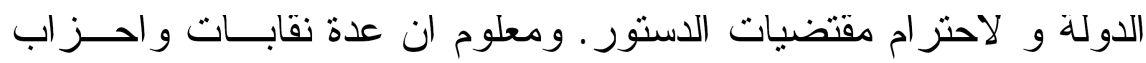

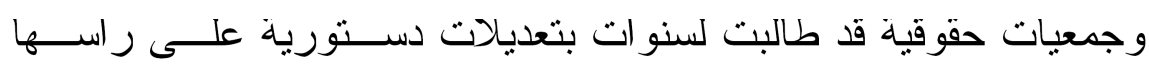

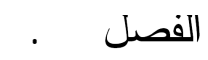

ولم يشر العاهل المغربي، باي شكل من الاشكال، إلى الانتفاضة التي

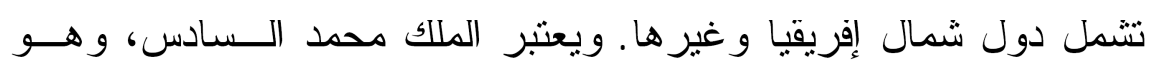

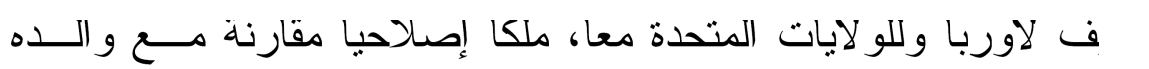
الحسن التاني دي القبضة الحديدية، رغم ان حقوق الإنسان فــي الـــبادد

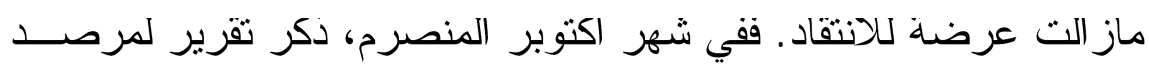

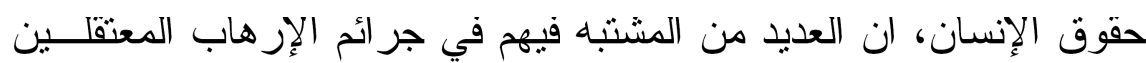
يتعرضون لخروق عدبدة، بيد ان الحكومة تنفي هذه الادعاءات (OV). 
على الرغم من إعلان الملك محمد الساد، منذ بداية عهده، النشبث. بالاختبار ات الكبرى للنظام السياسي كما كانت عليه في عهد الملك الر احل

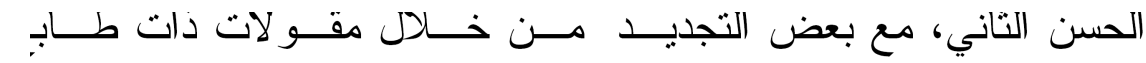

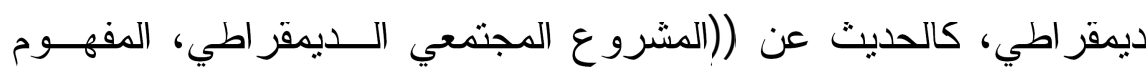
الجديد للسلطة، التذبير الفعال، خدمة المو اطن و التتمبة، و اجب المواطنة، النظام الديمقر اطي، دولة الحق و القانون، الدمقرطة، التحديث الــشامل))..

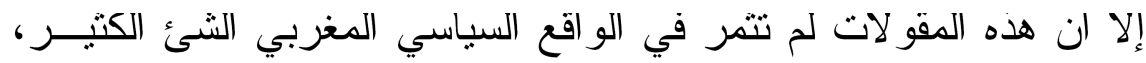
رغم ما صاحبها من مبادرات عملية، بل ان بعض هذه المباد المبادر ات شكلت

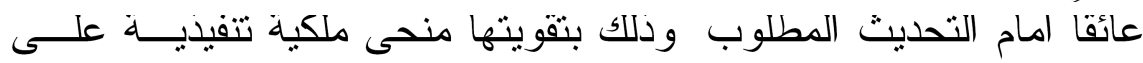

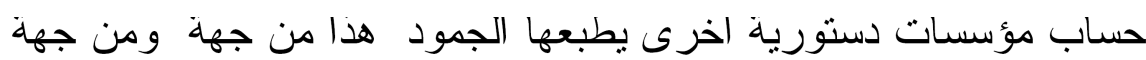

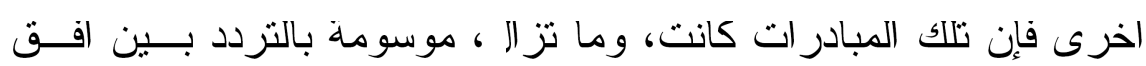

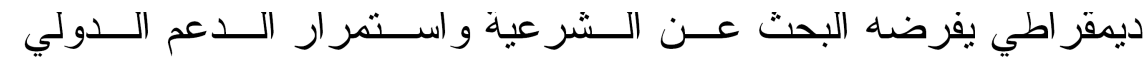

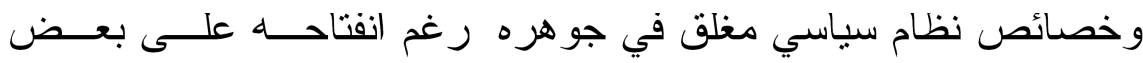
إشكال الديمقر اطية.

غير انه يمكن القول ان هناك العديد من الانتقادات التي توجه لعمليـــة التحول الديمقر اطي من اهمها:

- حصر اشكالياته في مستوى سطحي كونه يستهدف إحداث تعـديلات

$$
\text { دستورية حسب. }
$$

- استبعاد الحركة الإسلامية من التقدم برؤيتها او استشارتها في عملية

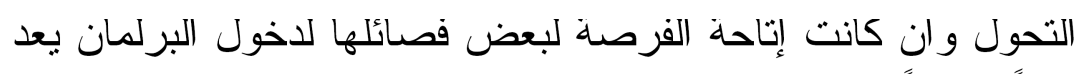
امراً ايجابياً في هذا لسيان. 


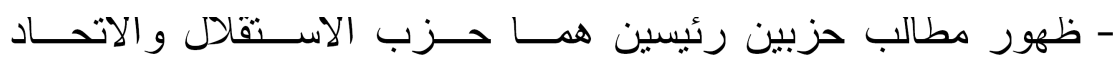
الاشتر اكي وكانهما الطرف الوحيد الذي بحظى بالثر عية في المطالبة بالتحو لات مقابل نزع الشر عية عن المنافسين. - هيمنة الملك على قلب الحياة السياسية في المغرب و إصر اره على على إن يملك ويحكم معا، و استخدامه العديد من السبل التي تدعم هذا الهدف، لهي

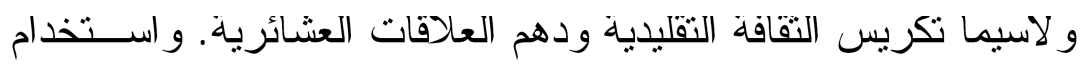
ستر اتيجية الموازنة الحزبية التي تضعف الاحزية اب التي تقتقد الطابع المؤسسي بالفعل.

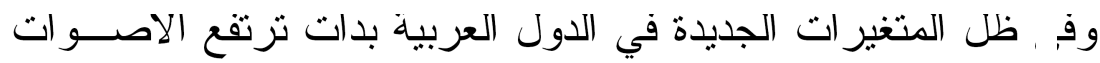
في الاوساط السياسية و التقافية و الإعلامية وحتى الامنية المغربية منسائلة بنوع من النشكيك المشروع، هل المغرب محصن من رياح التغيير الذي وني

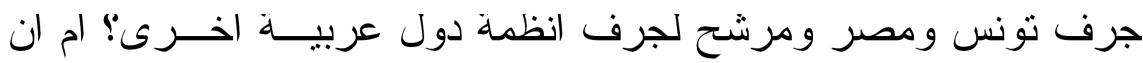

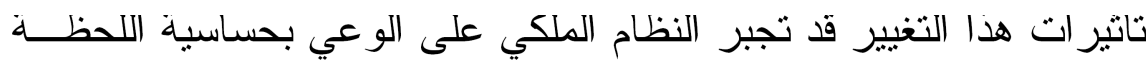

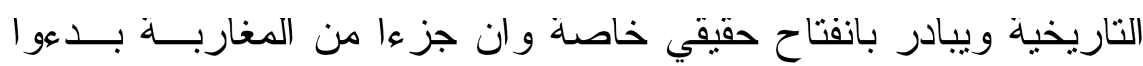

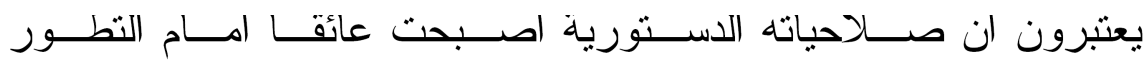
الديمقر اطي؟ - مئ.

المغرب من الدول التي بدات تثاثر برياح الديمقر اطبة التي تهب على

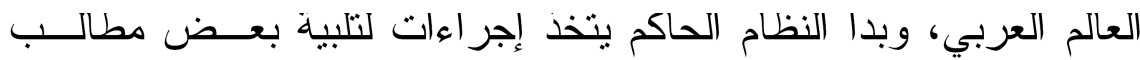

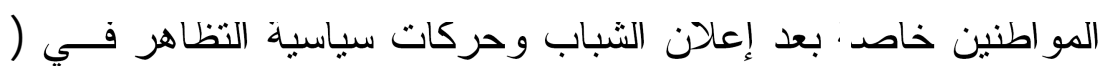
شباط )، وان كانت الإجر اءات المتخذة لاتزقى للمطالب الحقبقة التي

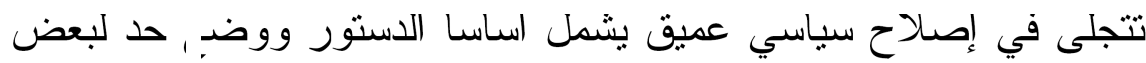
الممارسات السياسية و المالية المتهورة.

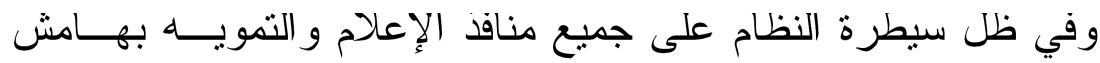

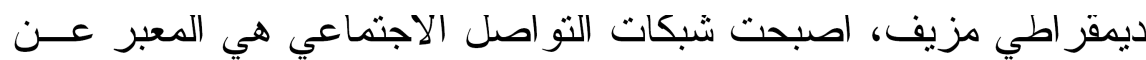

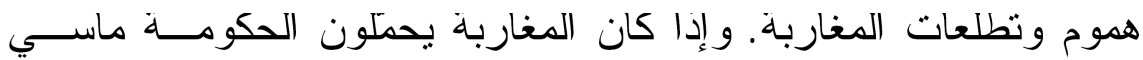


الشعب، فالخطاب بدا يتطور، فقد انتقل إلى محيط الملك اما الان فالبعض يسالل الملك محمد السادس مباشرة بحكم توفره وفق الدستور على جميع

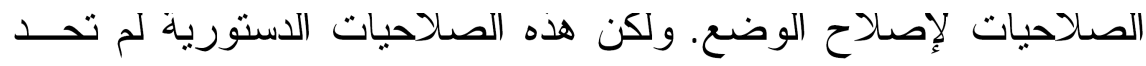
من الفوارق الاجتماعية التي تتفاقم، و اصبحت خروقات هقه حقوق الإنـسـان

$$
\text { فظبعة. مني. }
$$

و إذا كان المنطق يؤكد ان الملكية هي ضمان الاستقرار فــي الــبلاد،

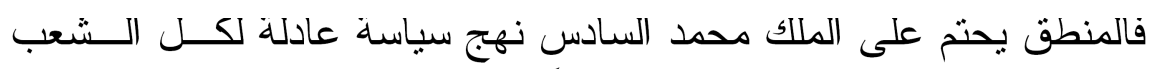

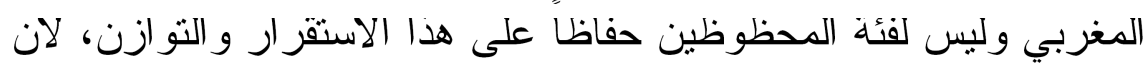

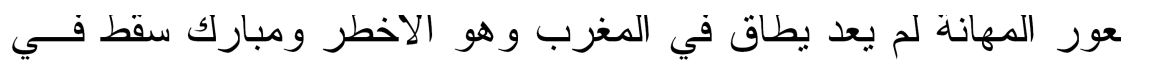

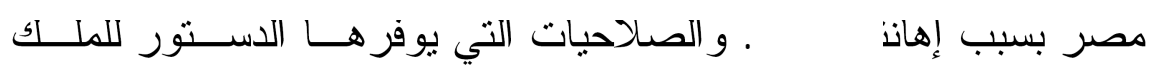

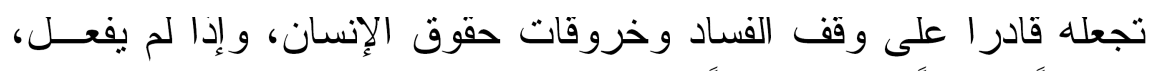

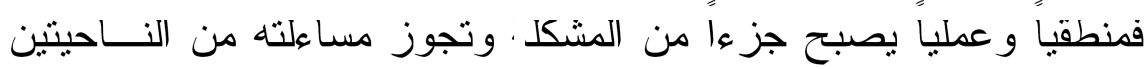
الاينية و السياسية. 


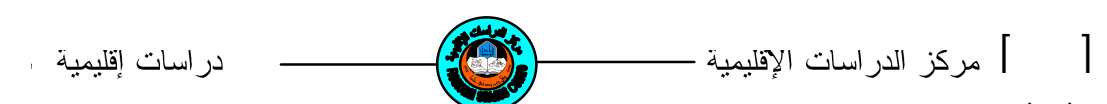

(ro)

\title{
The problematic conciliation between the democratic conversion and the traditional inherited of the Moroccan political system
}

\author{
Mobamed Saleh Shtaile \\ Assist lectures / Callege of palitical science/University of Mosul
}

\begin{abstract}
The reality of the contemporary Moroccan political system today is determined depending on three fundamental considerations:religion. Moroccan fraditions and the stage demand. Emerging from these three considerations, we find three types of legislation: the historic source, norm, the written constitution and each type is coming with certain "constitutional" field, So, the constitution is made to achieve the process of formulation to these types, but inspite of that there is agreat contradiction among the Islamic and historic thoughtsthat represented by believers principality in chapter 19 of Moroccan contitution, and the iden that the honorable ancestry of the King who belong himself the munificent messenger. The what is called (traditional), and throgh the who try to combine this tradition by modernity through the conttitution and the guoted thoughts from the Western constitution specially the Frenchone, that- what is the political, intellectual and ideological link constitutionally unstable and non- balanced.
\end{abstract}




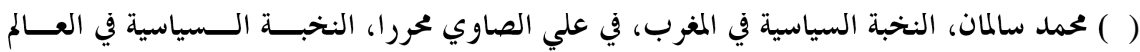

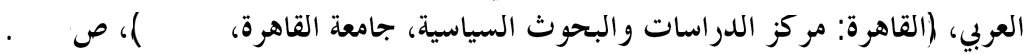

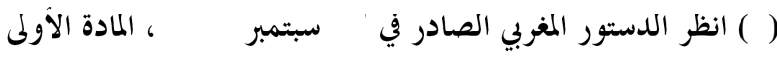

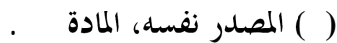

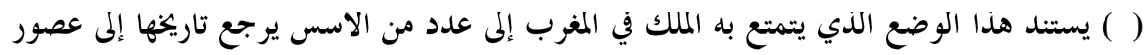

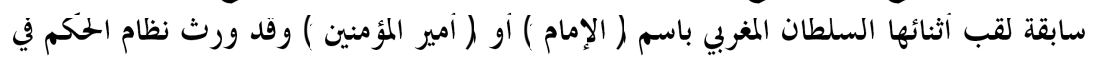

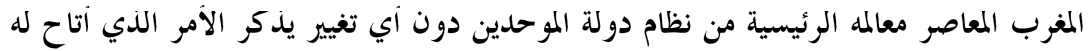

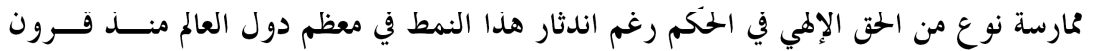

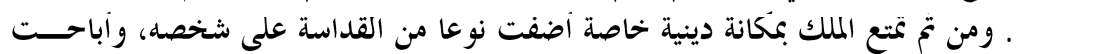

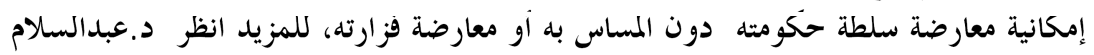

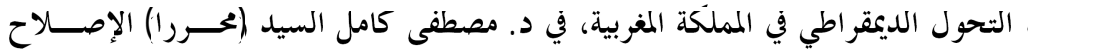

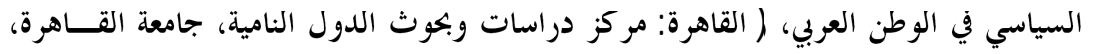

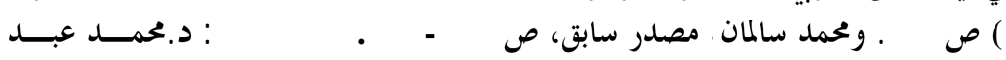

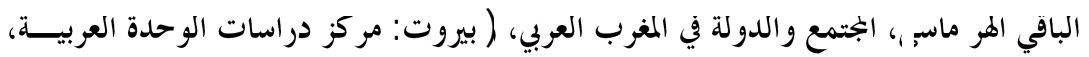

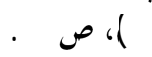

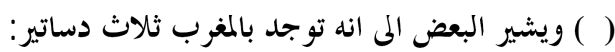

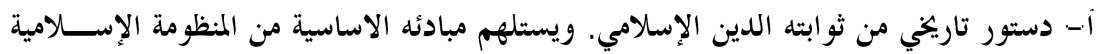

$$
\text { وهو دستور بضبط العلاقة بين الأمة والاميزر الإين }
$$

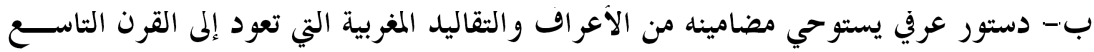

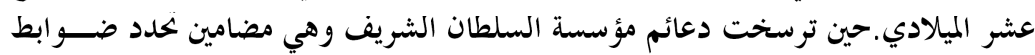
علاقات الرعية - القبائل - بالسلطان.

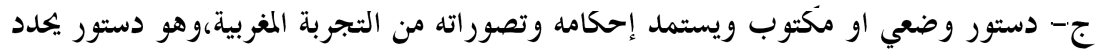

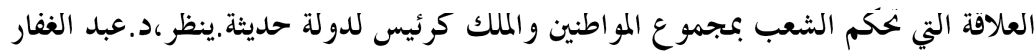

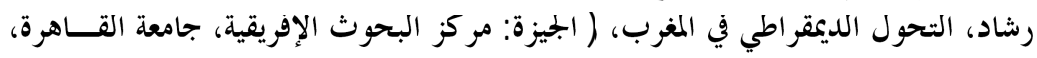

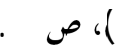
( ) د. احمد ثابت، التحول الديمقراطي في المغرب،( الجيزة! مركز البحوث والدراسات الـسسياسية،

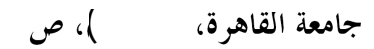

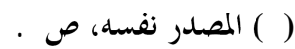

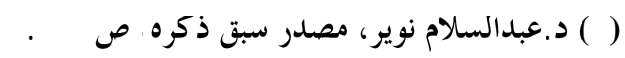

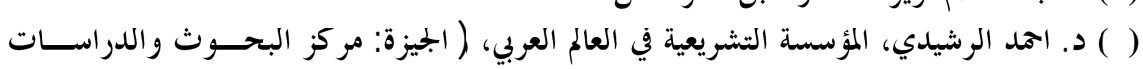

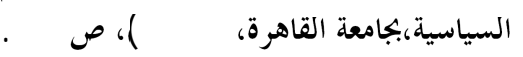




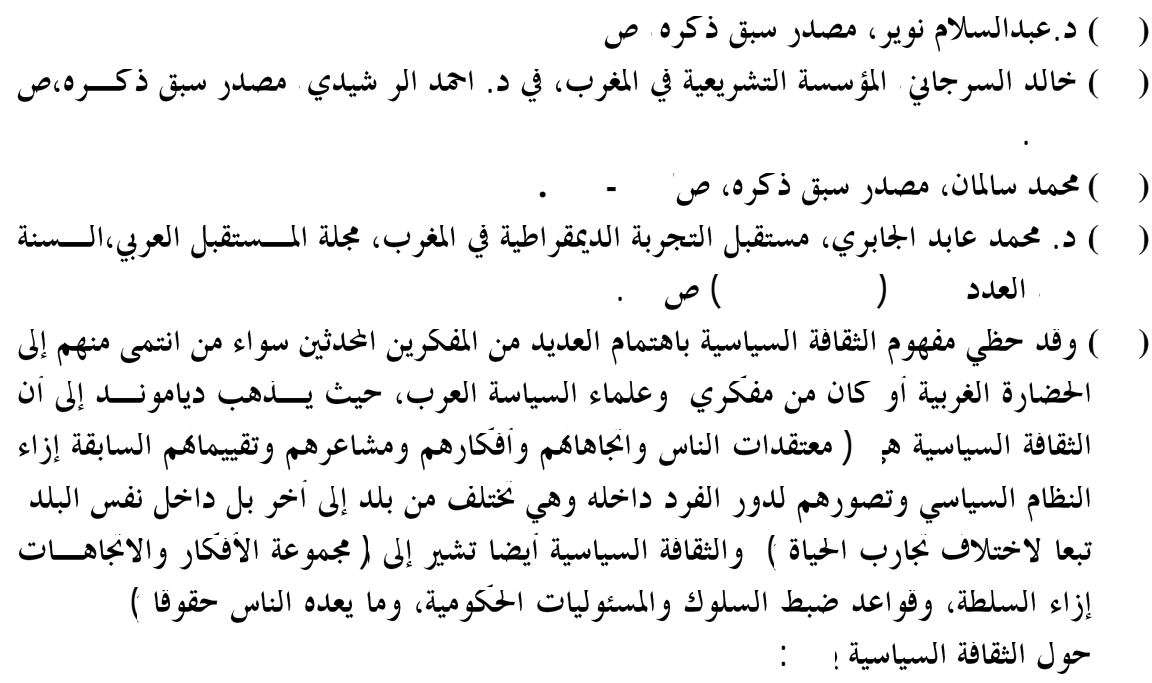

Larry Diamond, Intrroduction: Political Culture and Democracy, in: Larry Diamond, (Ed) P: Political Culture and -Democracy in Developing Countries, ( London: Lynne Rienner Publishers,1993 ), p,1.

David Robertson, The Penguin Dictionary Polities, ( London : Penguin books, 1993), p,362

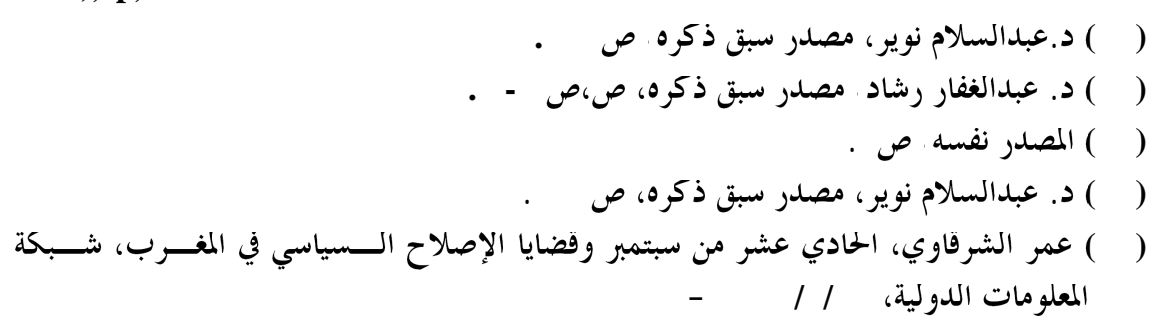

http://www.ahewar.org/debat/show.art.asp?aid

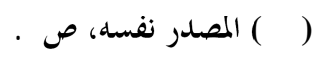

( ) د. هدى متيكس،،الإصلاح السياسي في دول التعددية السياسي،في د. مصطفى كامل السيد،

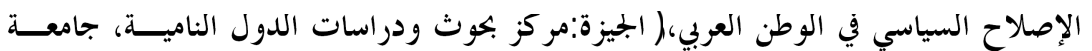

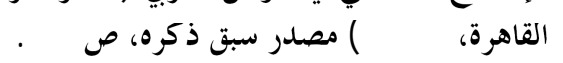

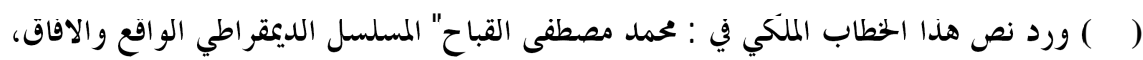

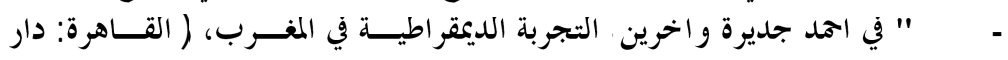

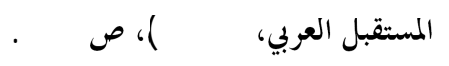




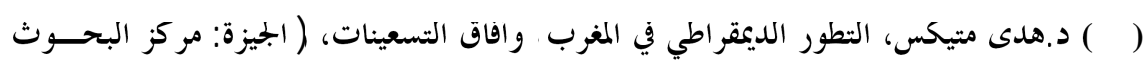

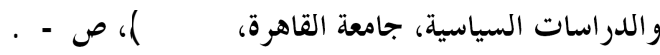

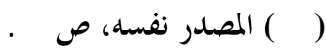

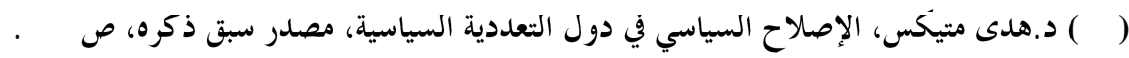

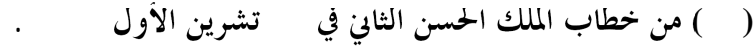

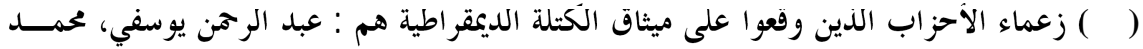

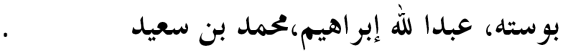

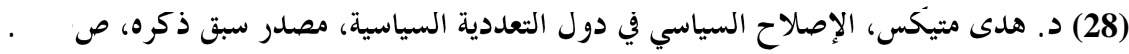

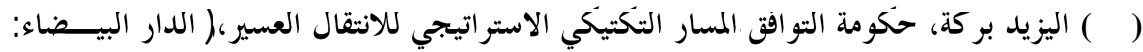

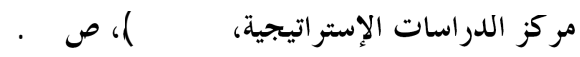

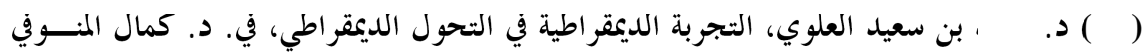

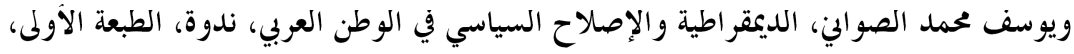

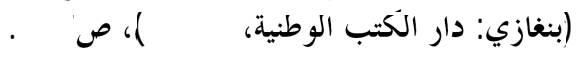

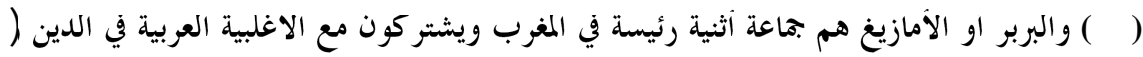

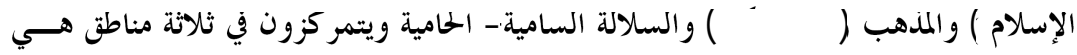

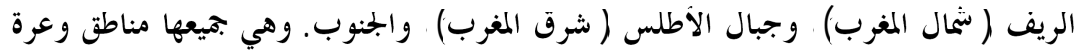

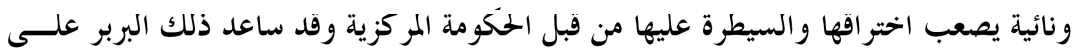

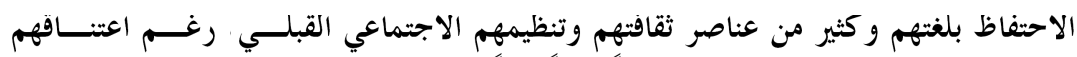

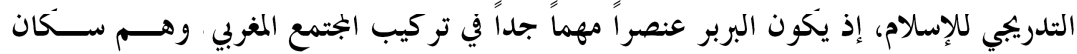

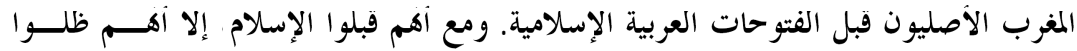

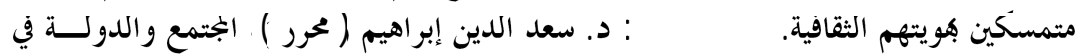

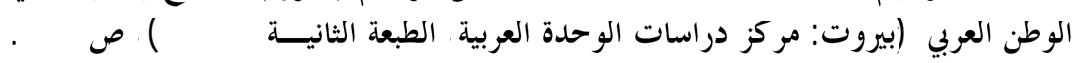

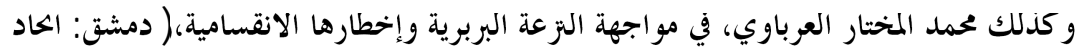

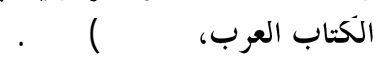

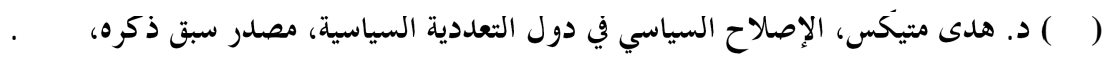

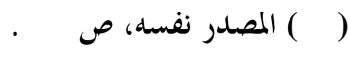

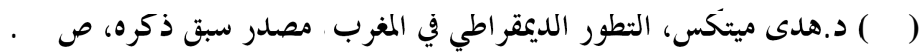

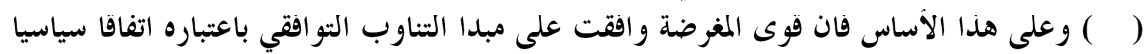
وليس استنادا إلى الدستورن

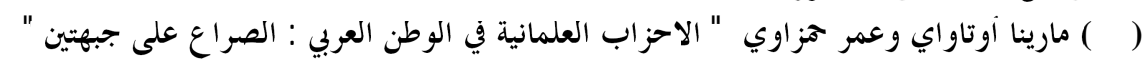

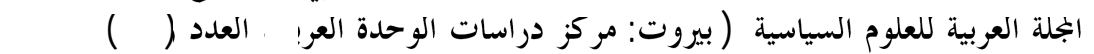




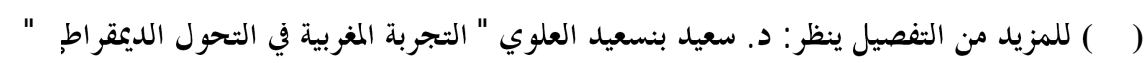

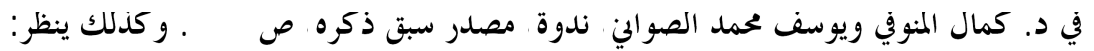

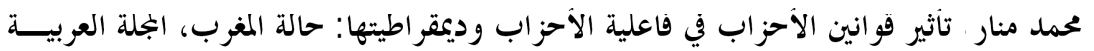

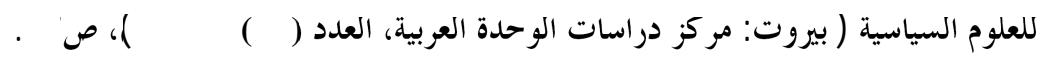

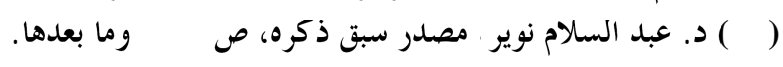

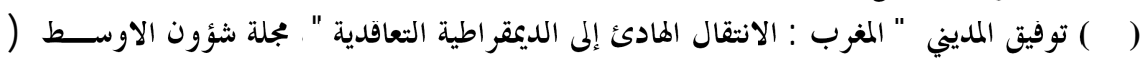

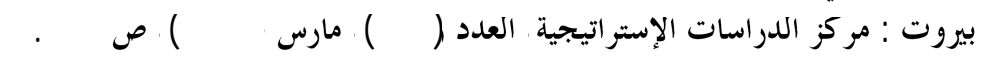

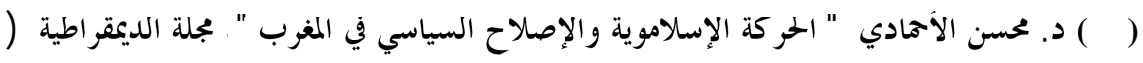

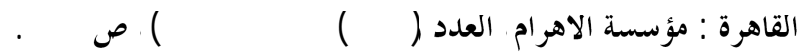

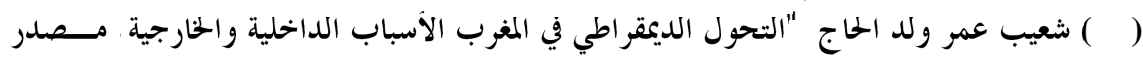

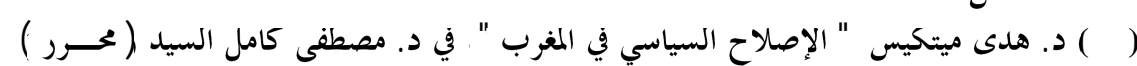

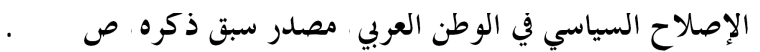

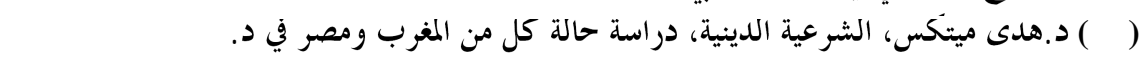

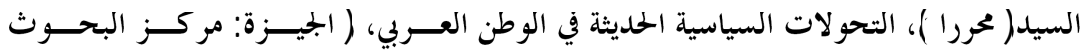

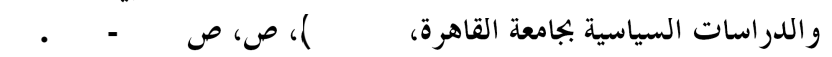

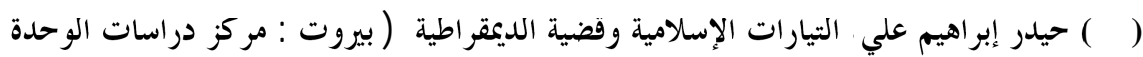

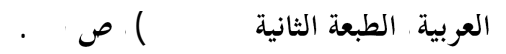

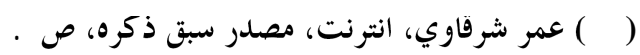

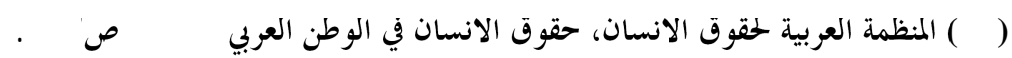

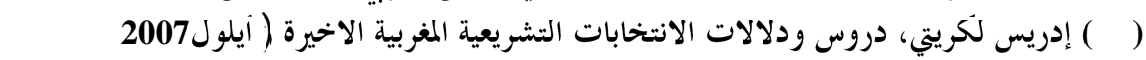

http://www.grenc.com المعلومات الدولية،

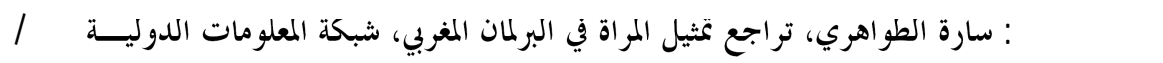

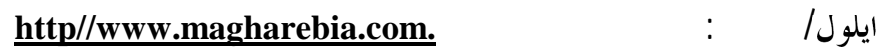

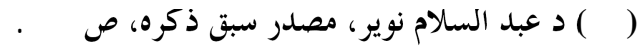

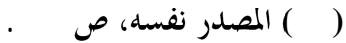

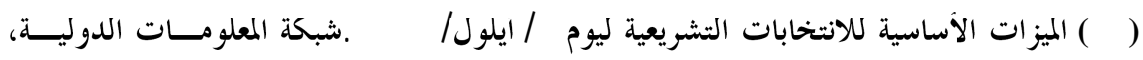

http://www.achr

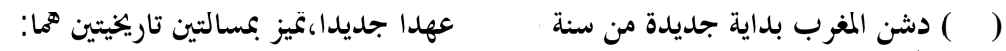

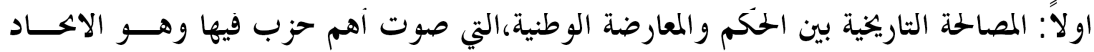

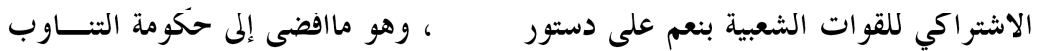

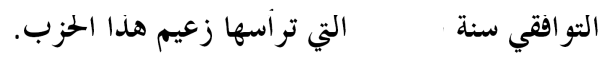




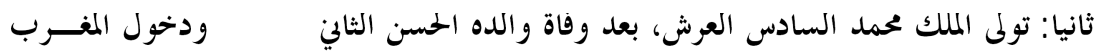

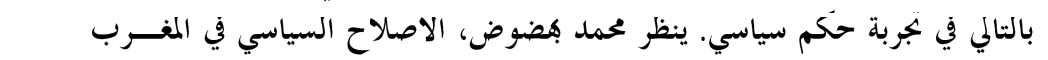

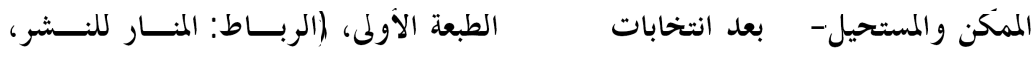

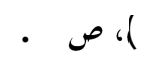

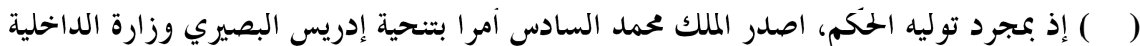

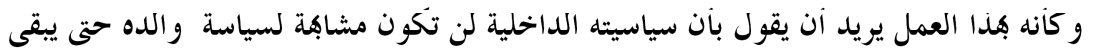

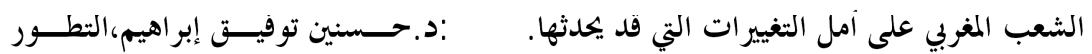

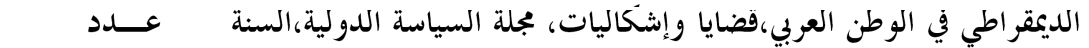

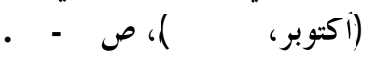

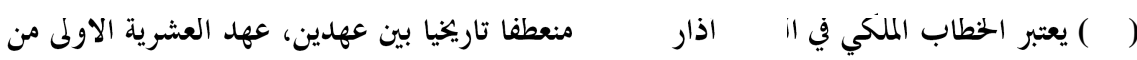

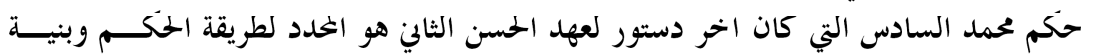

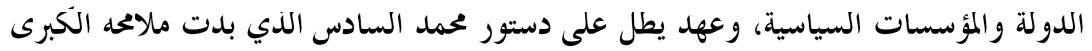

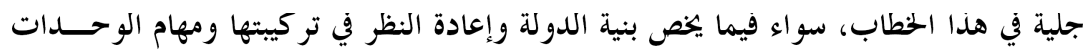

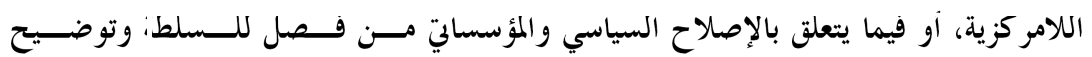

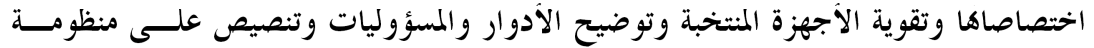

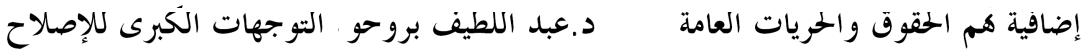
1 I / 1

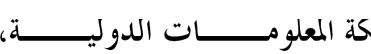

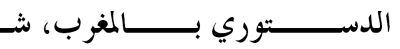

\section{http://www.facebook.com}

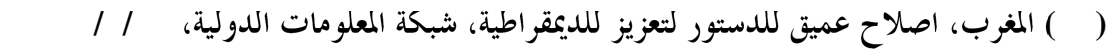
http://www.facebook.com

( ) الخطاب الملكي في الصحافة الدولية: جلالة الملك محمد السادس يتعهد بالإصلاح فيما يواجـــه.

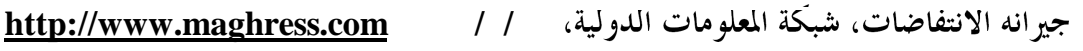

